\section{Low Tunnel and Cultivar Effects on Day-neutral Strawberry Yield and Characteristics in New Hampshire}

\author{
Kaitlyn M. Orde ${ }^{1}$ and Rebecca Grube Sideman ${ }^{1}$
}

ADDITIONAL INDEX WORDs. everbearing, Fragaria $\times$ ananassa, low tunnel temperature, protected culture, runners, soluble solids content

$\overline{\text { SUMMARY. Day-neutral strawberry (Fragaria } \times \text { ananassa) cultivars show promise for }}$ extending the fruiting season and increasing production in the northeastern United States, but published research on cultivar yield in the region is lacking. Furthermore, few studies have investigated the effects of low tunnels on yield, fruit, and plant characteristics. We evaluated eight day-neutral cultivars (Albion, Aromas, Cabrillo, Monterey, Portola, San Andreas, Seascape, and Sweet Ann) on open beds and under low tunnels in two separate experiments conducted in 2017 and 2018. Cultivars began producing ripe fruit within 10 weeks of planting in both years, and continued producing fruit without interruption for 20 weeks $(2017)$ and 18 weeks (2018). Annual total yield ranged from 234.9 to $497.8 \mathrm{~g} /$ plant and marketable yield ranged 126.4 to $389.1 \mathrm{~g} /$ plant, depending on cultivar and year. Cultivar significantly affected the percent marketable yield, late season yield, fruit size, soluble solids content (SSC), runner emergence, and plant size. Except for the cultivar Sweet Ann, low tunnels did not increase season-long marketable or total yield, but did increase the percent marketable yield for all cultivars in 2017 , and most cultivars in 2018. Furthermore, marketable yield was significantly greater under low tunnels than open beds during 6 late-season weeks in 2018. Fruit SSC was greater under low tunnels in 2018, and low tunnels reduced runner emergence for certain cultivars. Season-long average air temperatures were higher under low tunnels, but the greatest temperature differences occurred when low tunnels were closed. We demonstrate that day-neutral cultivars can produce high annual yields in New England, but that cultivar selection is paramount.

S trawberry is an important source of early-season income on farms across New England (Bornt et al., 1998; Grubinger, 2012), where it is estimated there are more than 1000 acres in production on 884 farms (U.S. Department of Agriculture

Received for publication 13 Feb. 2019. Accepted for publication 20 June 2019

Published online 20 September 2019

${ }^{1}$ Department of Agriculture, Nutrition and Food Systems, University of New Hampshire, 38 Academic Way, Durham, NH 03824

We thank farm, greenhouse, and technical staff at the University of New Hampshire. We also thank Cathy Neal and Maria Cramer for providing thoughtful reviews of our manuscript. This work was funded by the National Institute of Food and Agriculture, U.S Department of Agriculture, Specialty Crops Research Initiative under Award Number 2014-51181-22380 (Tunnel Berries). Partial funding was provided by the New Hampshire Vegetable and Berry Growers' Association and the New Hampshire Agricultural Experiment Station. This is Scientific Contribution Number 2807. This work was supported by the USDA National Institute of Food and Agriculture Hatch Project $\mathrm{NH} 00635$.

R.G.S. is the corresponding author. E-mail: becky. sideman@unh.edu.

This is an open access article distributed under the CC BY-NC-ND license (https://creativecommons.org/ licenses/by-nc-nd/4.0/).

https://doi.org/10.21273/HORTTECH04317-19
National Agricultural Statistics Service, 2018) and locally produced strawberry fruit are highly regarded by consumers. Short-day cultivars (Junebearers) have long been popular in the region for their winterhardiness and low establishment costs (Black et al., 2002; Pritts and Handley, 1998), but regional dependence on these cultivars has prevented growers from participating in the commercial strawberry market outside their brief 4- to 6-week fruiting period each year (Pritts and Handley, 1998).

Day-neutral (DN) strawberry cultivars are less affected by daylength and typically continue to flower as long as temperatures remain between 40 and $85^{\circ} \mathrm{F}$, resulting in a substantially longer fruiting period compared with short-day plants (Pritts and Handley, 1998; Rowley et al., 2010). Furthermore, DN plants produce ripe fruit $\approx 10$ weeks after planting, not the following year as with short-day plants (Pritts and Handley, 1998), reducing the period of crop management before financial return (Bornt et al., 1998).

DN cultivars have largely been developed for regions of the United States with substantial acreage in strawberry production, namely California and Florida (Lawrence et al., 1990). However, following the adoption of the plasticulture production system (Poling, 1993), early field trials in North Carolina showed that cultivars could produce as much as $1.02 \mathrm{~kg} /$ plant annually on the east coast of the United States (Ballington et al., 2008), suggesting great potential for DN production across the country. Recently, cultivar evaluations conducted from the mid-Atlantic region of the United States to as far north as Quebec, Canada, indicate that DN productivity is influenced by cultivar, site, and growing season, and annual marketable yields have ranged from between 189 and $950 \mathrm{~g} /$ plant (Condori et al., 2017; Lewers et al., 2017; Petran et al., 2016; Pritts, 2017a; Pritts and McDermott, 2017; Van Sterthem et al., 2017; Weber et al., 2018). Using a standard plasticulture plant spacing of 17,424 plants/acre (Lantz et al., 2010) such yields equate to between 8137 and $40,902 \mathrm{~kg} \cdot \mathrm{ha}^{-1}$, well exceeding the $5900 \mathrm{lb} /$ acre $\left(6613 \mathrm{~kg} \cdot \mathrm{ha}^{-1}\right)$ harvested by New England growers (U.S. Department of Agriculture National Agricultural Statistics Service, 2018). This strongly suggests that DN strawberry cultivars may not only extend

\begin{tabular}{llll}
\hline $\begin{array}{l}\text { Units } \\
\text { To convert U.S. to SI, } \\
\text { multiply by }\end{array}$ & U.S. unit & SI unit & $\begin{array}{l}\text { To convert SI to U.S., } \\
\text { multiply by }\end{array}$ \\
\hline 0.4047 & acre $(\mathrm{s})$ & $\mathrm{ha}$ & $2.471 \mathrm{l}$ \\
73.0778 & $\mathrm{fl} \mathrm{oz} / \mathrm{acre}$ & $\mathrm{mL} \cdot \mathrm{ha}^{-1}$ & 0.0137 \\
0.3048 & $\mathrm{ft}$ & $\mathrm{m}$ & 3.2808 \\
2.54 & inch $(\mathrm{es})$ & $\mathrm{cm}$ & 0.3937 \\
0.4536 & $\mathrm{lb}$ & $\mathrm{kg}$ & 2.2046 \\
1.1209 & $\mathrm{lb} / \mathrm{acre}$ & $\mathrm{kg} \cdot \mathrm{ha}^{-1}$ & 0.8922 \\
0.0254 & mil(s) & $\mathrm{mm}$ & 39.3701 \\
1.6093 & mile $(\mathrm{s})$ & $\mathrm{km}$ & 0.6214 \\
28.3495 & $\mathrm{oz}$ & $\mathrm{g}$ & 0.0353 \\
$\left({ }^{\circ} \mathrm{F}-32\right) \div 1.8$ & $\mathrm{o} F$ & ${ }^{\circ} \mathrm{C}$ & $\left({ }^{\circ} \mathrm{C} \times 1.8\right)+32$ \\
& & &
\end{tabular}


the fruiting period, but also offer high annual yields compared with shortday plants.

There are only a limited number of commercial farmers growing $\mathrm{DN}$ cultivars in New England. Anecdotally, the cultivars Albion, San Andreas, and Seascape are the most commonly grown, with select farmers reporting yields exceeding 25,000 lb/acre. While there have been exploratory trials at universities in the region (Handley, 2008; A. Radin, personal communication), to our knowledge, no replicated studies have been published and yield data are not available. Studies outside New England show tremendous variation in annual yield among sites, highlighting the need for region-specific research. For example, 'Seascape' was among the lowest yielding cultivars in Minnesota, but among the highest yielding in Maryland and New York (Lewers et al., 2017; Petran et al., 2016; Pritts, 2017a).

Several studies have found that low tunnel protective structures increase the marketable yield (grams per plant) and/or the percent marketable yield, especially late in the season and following weather events (Lewers et al., 2017; Petran et al., 2016; Pritts, 2017a; Resende et al., 2010; Van Sterthem et al., 2017). This suggests that low tunnels may be a useful tool for protecting fruit marketability in regions with frequent precipitation events, such as throughout the northeastern United States, but little is known about low tunnel effects on plant growth and development.

Of particular interest is runner initiation, which has been cited as a barrier for the adoption of the plasticulture cultivation system (Handley et al., 2009). While runner removal is standard practice in plasticulture production (Voth and Bringhurst, 1990), many growers converting from the perennial matted-row cultivation system [where runners are not removed (Poling and Durner, 1986)], find the task costly and time consuming because substantial labor is required to remove runners by hand (Handley et al., 2009). The gibberellic acid synthesis inhibitor prohexadionecalcium (commonly known as Apogee; BASF Corp., Research Triangle Park, NC) has been approved in Canada to assist with runner management (BASF Canada, Mississauga, ON, Canada). However, despite trials in Maryland,
Massachusetts, and Maine showing that applications can significantly reduce runner initiation and even improve fruit yields in strawberry (Black, 2004; Green and Schloemann, 2010; Handley et al., 2009), the product has not been approved in the United States. Thus, other tools are needed.

Lewers (2013) has reported observing a reduction in runner emergence under low tunnels in field trials in Maryland, but to our knowledge, these effects have not been documented in any published studies. However, they are in line with other research showing the cultivars Chandler and Sweet Charlie produced fewer runners under high tunnel protected culture (Kadir et al., 2006). Total leaf area, shoot biomass (grams), leaf number, and the number of branch crowns have also been affected by high tunnels (Kadir et al., 2006), suggesting that protected culture may also influence plant size and even planting density.

Furthermore, recent experiments comparing the microclimate under low tunnels with the traditional open bed environment have reported that season-long air and soil temperatures are greater under low tunnels (Condori et al., 2017; Van Sterthem et al., 2017). Warmer temperatures have been associated with greater yields and an extended fruiting season, especially in the mid-Atlantic region where temperatures are milder than the northeastern United States (Condori et al., 2017; Lewers et al., 2017; Van Sterthem et al., 2017). Given these findings, it is important to understand the effect of low tunnels on microclimate and season duration in the northeastern United States, where summers are hot but nighttime temperatures can drop precipitously in the fall. Of particular interest is whether low tunnels increase temperatures during the summer months even when low tunnels are vented, and whether they provide any thermal insulation at night during the fall months, when they may be used to assist in season-extension. Experiments conducted in warmer regions suggest low tunnels do not provide a substantial buffer in nighttime temperatures (Condori et al., 2017; Van Sterthem et al., 2017), but since most studies present season-long averages, not daily fluctuations in temperature, this remains unclear.
The objectives of this study were to quantify the effects of low tunnel structures and DN cultivar on yield, fruit marketability, and fruit and plant characteristics. We were also interested in the impact of low tunnels on air and soil temperatures. Toward this end, we evaluated five relatively well-known DN cultivars: Albion, Monterey, Portola, San Andreas, and Seascape, as well as three additional cultivars that may be candidates for our region: Aromas, Cabrillo, and Sweet Ann. Plants were grown on two production systems (called cover treatments): open beds and low tunnels. Data were collected on yield, fruit weight, the fruiting pattern of cultivars throughout the season (called fruiting pattern), fruit SSC, runner emergence, plant height, plant diameter, and average, maximum, and minimum air and soil temperatures.

\section{Materials and methods Site description}

Experiments were conducted at the University of New Hampshire Agricultural Experiment Station Woodman Horticultural Research Farm in Durham, NH (lat. $43^{\circ} 15^{\prime} \mathrm{N}$, long. $\left.70^{\circ} 93^{\prime} \mathrm{W}\right)$. The site is located in plant hardiness zone $5 \mathrm{~B}$ (U.S. Department of Agriculture, 2012) on Charlton fine sandy loam (coarseloamy, mixed, superactive, mesic Typic Dystrudept) (U.S. Department of Agriculture Natural Resource Conservation Service, 2016).

\section{Experimental design}

The experiment was arranged in a split-plot, randomized complete block design with four replications. The main-plot was cover treatment, and the sub-plot was cultivar (Supplemental Fig. 1). Two cover treatments were investigated: a traditional uncovered bed (henceforth referred to as "open bed") and a bed covered by a low tunnel ("low tunnel"). A total of six cultivars were evaluated in 2017 and seven in 2018 (Table 1). Each block consisted of two rows, one of each cover treatment, for a total of eight rows. Sub-plots of each cultivar ("plots") consisted of 10 plants in 2017 and 14 plants in 2018, and were established one directly after another the length of each row. Guard plants were planted at both ends of all eight rows to prevent an edge effect. In 2017, two 'Albion' 
Table 1. Cultivar name, plant source, patent date, inventor, and pedigree of day-neutral strawberry cultivars grown on open beds and under low tunnels covered by $1.5-\mathrm{mil}(0.038 \mathrm{~mm})$ plastic at the University of New Hampshire in Durham in 2017 and 2018.

\begin{tabular}{|c|c|c|c|c|c|}
\hline Cultivar & Plant source & $\begin{array}{l}\text { Date of } \\
\text { patent }^{z}\end{array}$ & $\begin{array}{c}\text { Inventor and } \\
\text { applicant/assignee }^{\mathrm{z}}\end{array}$ & Pedigree $^{\mathrm{z}}$ & $\begin{array}{l}\text { Yr(s) included in } \\
\text { experiments }\end{array}$ \\
\hline Albion & $\begin{array}{l}\text { Nourse Farms } \\
\text { (Deerfield, MA) }\end{array}$ & 2006 & $\begin{array}{l}\text { D.V. Shaw and K.D. Larson, } \\
\text { University of California }\end{array}$ & 'Diamante' $\times$ Cal 94.16-1 & 2017,2018 \\
\hline Aromas & $\begin{array}{l}\text { U.S. Berry Plants } \\
\text { (Oak Harbor, WA) }\end{array}$ & 1998 & $\begin{array}{l}\text { D.V. Shaw, University } \\
\text { of California }\end{array}$ & Cal 87.112-6 × Cal 88.270-1 & 2017 \\
\hline Cabrillo & Nourse Farms & 2016 & $\begin{array}{l}\text { D.V. Shaw and K.D. Larson, } \\
\text { University of California }\end{array}$ & Cal 3.149-8 × Cal 5.206-5 & 2018 \\
\hline Portola & Nourse Farms & 2009 & $\begin{array}{l}\text { D.V. Shaw and K.D. Larson, } \\
\text { University of California }\end{array}$ & Cal 97.93-7 × Cal 97.209-1 & 2017,2018 \\
\hline San Andreas & Nourse Farms & 2009 & $\begin{array}{l}\text { D.V. Shaw and K.D. Larson, } \\
\text { University of California }\end{array}$ & ‘Albion’ × Cal 97.86-1 & 2017,2018 \\
\hline
\end{tabular}

plants were planted at both end of rows. In 2018, an additional sub-plot ('Albion', 'Cabrillo', or 'Sweet Ann') was planted at both ends of rows. Both cover treatment (main-plot) and cultivar (sub-plot) were randomly assigned within block and row, respectively.

\section{Crop establishment and management}

Experiments were conducted in 2017 and 2018, with a new field established in the spring of each year. Adjacent fields were used for experiments, both of which were cropped with brussels sprouts (Brassica oleracea Gemmifera Group) in the year before use. Soil was amended with $60 \mathrm{lb} /$ acre of both nitrogen $[\mathrm{N}$ (27N-0P-0K, calcium ammonium nitrate; Kriby Agri, Lancaster, PA)] and potassium $[\mathrm{K}(0 \mathrm{~N}-0 \mathrm{P}-42.3 \mathrm{~K}$, sulfate of potash; North Country Organics, Bradford, VT) before bed formation based on soil test results and fertility recommendations for strawberry (Lantz et al., 2010; University of New Hampshire, 2016). Raised beds measuring 4 inches high and 24 inches wide were laid in the spring of both years. The distance between beds was $6 \mathrm{ft}$ (center to center), as is often typical on strawberry farms due to equipment availability (Lantz et al., 2010). Beds were covered with 1.25-mil embossed black plastic mulch (Poly Expert, Laval, QC, Canada) and equipped with a 10-mil single line of drip irrigation tape with a 12 -inch emitter spacing (T-tape; Rivulis Eurodrip, San Diego, CA).

Dormant bare-rooted strawberry plants were acquired from commercial nurseries (Table 1) and planted on 28 Apr. 2017 and 7 May 2018 , with the exception of 'Cabrillo' and 'Sweet Ann' which were planted on 11 May 2018 due to a delayed shipment from the supplier. Plants were set in double staggered rows 12 inches apart with an in-row spacing of 16 inches between plants. A 16-inch in-row spacing has been recommended for high vigor cultivars and sites (Lantz et al., 2010), and was selected to ensure vigorous cultivars had adequate space. The first flush of flower trusses was removed in both years to encourage plant establishment. This period spanned from 18 May through 1 June 2017, and 25 May to 5 June 2018.

Additional nutrition was provided to plants once per week through the drip irrigation system from 12 June to 27 Oct. 2017 and from 2 July 2018 to 17 Oct. 2018. In 2017 , fertigation began at a rate of $2.5 \mathrm{lb} /$ acre N, $0.6 \mathrm{lb} /$ acre P, $2.4 \mathrm{lb} /$ acre K (21N-2.2P-16.6K; Jack's All Purpose LX soluble fertilizer; JR Peters, Allentown, PA). When a foliar nutrient analysis conducted in July 2017 indicated plants were below the optimal range of $\mathrm{N}$ and $\mathrm{P}$, application rates were increased to $5 \mathrm{lb} /$ acre $\mathrm{N}, 1.2 \mathrm{lb} /$ acre $\mathrm{P}$, and 4.7 lb/acre K on 1 Aug. 2017 and continued at this rate throughout the remainder of the 2017 season and the entire 2018 experiment.

High aphid (Superfamily: Aphidoidea) populations were managed with $1.2 \mathrm{fl} \mathrm{oz} /$ acre acetamiprid (Assail 30 SG; United Phosphorus Co., King of Prussia, PA) applied using a backpack sprayer on 26 June 2017. Oriental beetle (Anomala orientalis) soil grubs were managed in both years with one application of $4.28 \mathrm{fl} \mathrm{oz} /$ acre imidacloprid (Admire Pro; Bayer CropScience, Research Triangle Park, NC) applied through the drip irrigation system on 4 Aug. 2017 and 25 July 2018. Insecticides were applied to ensure the crop was not seriously damaged or lost due to high pest pressure at this site, as oriental beetle grubs have been a serious problem at the site in the past. Although imidacloprid required a 14-d preharvest interval, fruit produced during this time were harvested and included in yield totals but were not consumed. Given the high number of organic and lowspray farms in our region, fungicides were not applied throughout experiments to determine the effects of low tunnel structures on fruit marketability under low-spray conditions.

\section{Low tunnel establishment and management}

The low tunnel cover treatment was constructed on 24 May 2017 and 29 May 2018, after planting. As in 
other experiments (Lewers et al., 2017), low tunnels were erected shortly after planting in both years to protect plants from precipitation during all stages of plant and fruit development. A complete commercial low tunnel system was used (Tunnel Flex; Dubois Agrinovations, SaintRemi, QC, Canada), containing hoops $(0.7 \mathrm{~m}$ wide $\times 1.0 \mathrm{~m}$ high $)$, grounding stakes for hoops, and anchor pipes for the low tunnel film. Low tunnels were covered with a 1.5 -mil film designed specifically for low tunnels that contained small circular holes for ventilation on the lower $30.5 \mathrm{~cm}$ of the tunnel (Trioplast AB; Smalandsstenar, Sweden and Dubois Agrinovations).

The sides of low tunnels were raised for the majority of the growing season to prevent excessively high temperatures inside tunnels, which have inhibited fruit set in other studies (Lewers et al., 2017). Low tunnel sides were closed as needed for precipitation, but were opened immediately following precipitation or early the following morning if rain occurred overnight. Low tunnel sides were permanently closed for the remainder of the growing season (except for harvest) when nighttime temperatures consistently dropped below $32{ }^{\circ} \mathrm{F}$. This occurred on 31 Oct. 2017 and l Oct. 2018.

\section{Data collection}

YIELD AND FRUIT WeIght. Fruit were harvested twice per week until 31 Oct., after which fruit were harvested once per week until low temperatures froze fruit. All ripe fruit from a given plot were separated into marketable and unmarketable groups, and weighed and counted by group. The average per plant yield was calculated by dividing the total plot yield by the number of living plants in that plot at harvest. Mean fruit weight was calculated by dividing the total plot yield by the number of fruit harvested from the plot. Fruit were considered unmarketable if they weighed less than $7.0 \mathrm{~g}$, were damaged from contact with water (having cracks, a jelly-like texture, or rotten tip), were misshapen, covered by soil, or rotten. The primary pathogens responsible for fruit rots were Botrytis cinerea and anthracnose (Colletotrichum acutatum).

SSC. SSC data were collected at three similar dates in each year: earlyAugust (1 Aug. 2017 and 6 Aug.
2018), late-August (25 Aug. 2017 and 24 Aug. 2018), and early-October (6 Oct. 2017 and 1 Oct. 2018). The sap of 10 individual fruit from each plot were measured by removing the tip of the receptacle $(\approx 0.5 \mathrm{~cm})$ and extracting sap onto the lens of a digital refractometer (model HI96801; Hanna Instruments, Woonsocket, RI). The percent SSC was first recorded for each fruit individually, and then averaged for a mean value for each plot.

RunNers. Runners were removed and counted once per month. Each time runners were removed, the average number of runners per plant was determined by dividing the total number of runners removed from a plot by the number living plants in that plot. A season-long cumulative number of runners per plant was determined by totaling the number of runners removed at all dates. Runner removal dates in 2017 were 23 June, 20 July, 15 Aug., 11 Sept., and 13 Oct. Runner removal dates in 2018 were 27 July, 27 Aug., and 21 Sept.

Plant height AND DiameTer. Height and diameter measurements were collected from the innermost six plants within a plot. All six measurements were averaged for a mean height and a mean diameter value for each plot. Height was determined by measuring from the base of the plant to the tallest point of living foliage, including flower trusses. Plant diameter was measured parallel to the edge of the raised bed, and included all living foliage and flower trusses. Plant height and diameter were measured twice in 2017 (5 Sept. and 15 Nov.), and four times in 2018 (13 July, 16 Aug., 19 Sept., and 12 Nov.).

Temperature. In 2018, air and soil temperatures were recorded for both cover treatments at hourly intervals using outdoor temperature sensors (Hobo U12-008 4-channel logger; Onset Computer Corp., Bourne, MA) from 10 July 2018 through 31 Oct. 2018. One temperature sensor was randomly placed in each row so that there were four replications of temperature sensors for each cover treatment. Air temperatures were collected under a solar radiation shield placed 12 inches above bed height. Soil temperatures were collected at soil depth of 3 inches.

Precipitation. Annual precipitation data were recorded by the University of New Hampshire
Weather Station located on the University's campus, which is 1.8 miles from the experiment location.

\section{Data analysis}

Using JMP Pro 13 (SAS Institute, Cary, NC), analysis of variance (ANOVA) was used to evaluate the effects of cover treatment (main plot), cultivar (sub-plot), and their interaction, on yield (marketable, total, and late season), weekly marketable yield, percent marketable yield by weight, fruit weight, SSC, cumulative runner production, plant height, plant diameter, and temperature. Percent marketable yield values were arcsine transformed before analyses to normalize the distribution. Average, maximum, and minimum air and soil temperature values were identified for each day of the season, and these daily values were used in the ANOVA. SSC, plant height, plant diameter, and temperature data were analyzed with date (or month, as in the case of temperature) as a repeated measure. Block was specified as a random effect. When an overall $\mathrm{F}$ test was significant $(P \leq 0.05)$, means were compared using Tukey's honestly significant difference test or Student's $t$ test at the $P \leq 0.05$ level. In the case of a significant interaction among treatments, results are explained and/or presented separately for all treatment combinations.

\section{Results}

Plants produced ripe fruit within 10 weeks of planting in both years, with harvests beginning on 28 June 2017 and 7 July 2018. Fruit production continued without interruption until 8 Nov. 2017 and 1 Nov. 2018 , for a total of 20 weeks in 2017 , and 18 weeks in 2018. During the period when plants were actively producing fruit in 2017, rainfall totaled 15.7 inches and there were $24 \mathrm{~d}$ when precipitation exceeded 0.10 inches (University of New Hampshire, 2018) (Fig. 1). By contrast, rainfall totaled 21.5 inches in 2018 and there were $30 \mathrm{~d}$ when precipitation exceeded 0.10 inches (University of New Hampshire, 2018), resulting in a noticeably wetter growing season.

\section{Yield and percent marketable yield}

When considering only the cultivars included in both years of our study (Albion, Monterey, Portola, 
San Andreas, and Seascape), year had a significant effect on total marketable yield $(P<0.0001)$, and the average marketable yield was greater in 2017 (318.0 g/plant) than 2018 (186.3 g/ plant). Since we observed such variation between years and only five of eight cultivars could be evaluated in both experiments, we have presented results separately by year to illustrate the variation in potential outcomes (Table 2).
Cover treatment did not affect marketable or total (marketable + unmarketable) yield in either year of our study, but cultivar significantly affected marketable and total yield in 2017 and $2018[P<0.0001,0.0001,0.001$, and 0.001 , respectively (Table 2$)]$. In 2017, 'Albion' had the greatest marketable yield (389.1 g/plant), comparable to 'Aromas' and 'Monterey', but significantly greater than 'Portola', 'San Andreas', and 'Seascape'. Total yields of 'Albion', 'Aromas', and 'Monterey' were also the highest, significantly greater than 'Portola' and 'San Andreas' (Table 2).

In 2018, we observed a significant cover $\times$ cultivar interaction for marketable ( $P=0.007$ ) yield (Table 2 ) because 'Sweet Ann' was the only cultivar with significantly greater yields under low tunnels (Fig. 2). 'Sweet Ann' produced 130.7 g/plant more under low tunnels than open

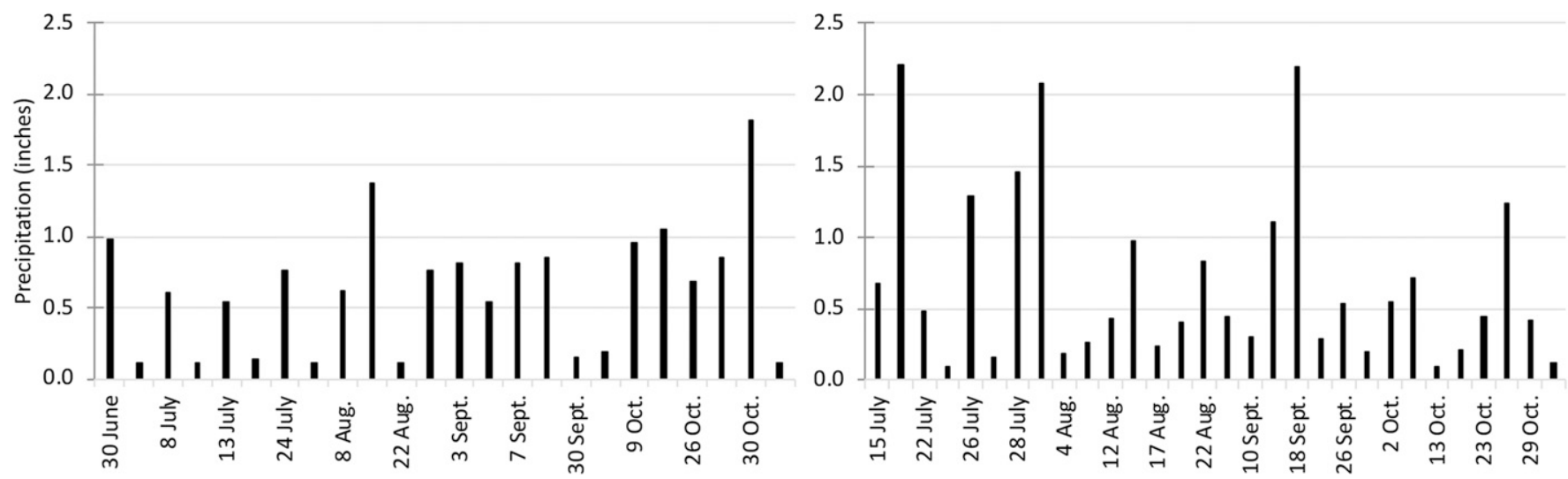

Fig. 1. Daily precipitation events exceeding 0.10 inches during the 2017 and 2018 growing seasons in Durham, NH. Graphs show precipitation during periods of fruit production only ( 28 June-8 Nov. 2017 and 2 July-1 Nov. 2018). Weather data provided by the University of New Hampshire (2018) weather station located 1.8 miles $(2.90 \mathrm{~km})$ from the experiment location; 1 inch $=2.54 \mathrm{~cm}$.

Table 2. Cover and cultivar effects on marketable, total (marketable + unmarketable), percent marketable, and late-season yield of eight day-neutral strawberry cultivars grown in separate experiments in 2017 and 2018 at the University of New Hampshire in Durham. Cover treatments were traditional open beds and low tunnels covered by $1.5-\mathrm{mil}(0.038 \mathrm{~mm})$ plastic. Dormant bare-rooted plants were established on black plastic mulch on 28 Apr. 2017 and 7 May 2018 and harvested 28 June-8 Nov. 2017 and 7 July-1 Nov. 2018.

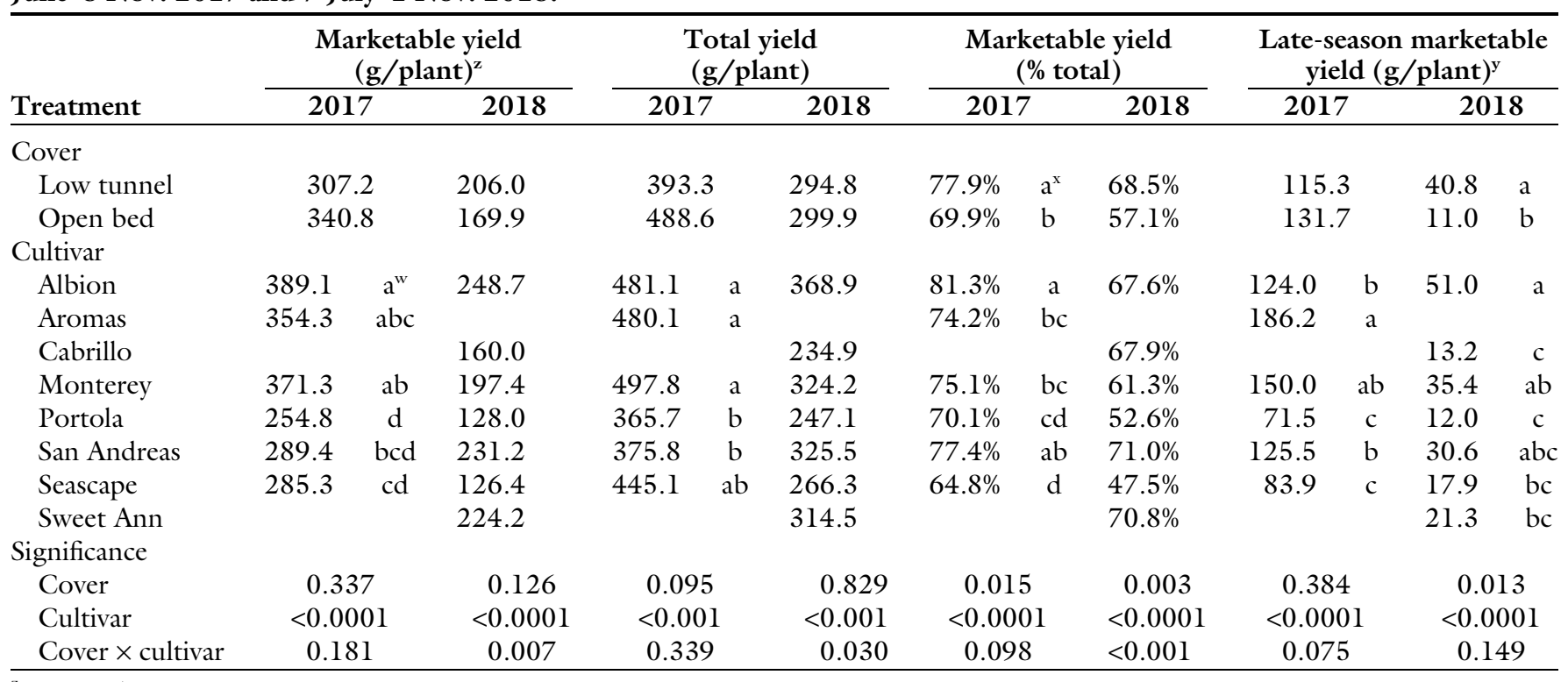

${ }^{\mathrm{z}} \mathrm{lg}=0.0353 \mathrm{oz}$.

'For the period of 24 Sept.-29 Oct. 2017 and 23 Sept.-28 Oct. 2018

${ }^{x}$ Within column, cover means followed by the same letter are not significantly different by Student's $t$ test $(P \leq 0.05)$.

wWithin column, cultivar means followed by the same letter are not significantly different by Tukey's honestly significant difference test $(P \leq 0.05)$. 
beds, making low tunnel 'Sweet Ann' the highest yielding treatment combination, followed by 'Albion' (262.2 g/plant) and 'San Andreas' (259.8 g/plant) under low tunnels (Fig. 2). For total yield in 2018 , a significant $(P=0.030)$ cover $\times$ cultivar interaction occurred (Table 2 ), because Cabrillo, San Andreas, and Sweet Ann had greater total yields under low tunnels, but Albion, Monterey, Portola, and Seascape did not (interaction not shown).

Low tunnels significantly increased the percent marketable yield (PMY) in 2017 ( $P=0.015)$, which was $8 \%$ greater under low tunnels than open beds. Cultivar also significantly affected the PMY in 2017 $(P<0.0001)$, with Albion producing the highest PMY $(81.3 \%)$ and Seascape, the lowest $(64.8 \%)$ (Table 2 ). In 2018, we detected a significant cover $\times$ cultivar interaction for PMY $[P=<0.001$ (Table 2) $]$ because Monterey, Portola, San Andreas, and Sweet Ann were the only cultivars with a significantly $(P \leq 0.05)$ greater PMY under low tunnels than open beds (Fig. 3). For these select cultivars, low tunnels increased the PMY by as little as 3.3\% (Seascape) to as much as $20.5 \%$ (Sweet Ann) (Fig. 3).

\section{Cultivar fruiting patterns and late- season yield}

We observed variation in the fruiting patterns of cultivars between the 2 years, largely because Albion, Monterey, San Andreas, and Seascape had increased productivity in lateSept. 2017, but not in 2018 (Fig. 4 ). The fruiting pattern of cultivars varied from relatively consistent (Albion and Monterey), to one (Cabrillo and Sweet Ann) or two (Aromas and Seascape) peaks in production, but within year, the fruiting pattern of a cultivar was similar between cover treatments (Fig. 4).

Treatment effects on marketable yield during six late-season weeks ( 24 Sept.-29 Oct. 2017 and 23 Sept.-28 Oct. 2018) are shown in Table 2. Marketable yield was significantly $(P<0.0001)$ influenced by cultivar in both years, with the highest yielding cultivars during this period being Aromas and Monterey in 2017, and Albion, Monterey, and San Andreas in 2018. Low tunnels increased late season yield in 2018, when marketable yield was 3.7 times greater under low tunnels than open beds during this 6 -week period [40.8 vs. $11.0 \mathrm{~g} /$ plant (Table 2)].

\section{Fruit weight}

In 2017, fruit weight was affected by cultivar $(P<0.0001)$, but not by cover treatment (Table 3 ). 'San Andreas' produced the largest fruit (13.9 g) and 'Seascape' produced the smallest $(10.8 \mathrm{~g})$. In
2018, we detected a significant $(P=$ $0.005)$ cover $\times$ cultivar interaction (Table 3) because San Andreas produced larger fruit on open beds (16.0 g) than under low tunnels $(12.4 \mathrm{~g})(P \leq$ $0.05)$. The weight of open bed 'San Andreas' was greater than all other cultivars, regardless of cover treatment $(P \leq 0.05)$. 'Sweet Ann' followed with the second heaviest fruit weight of 12.8 $\mathrm{g}$ under low tunnels and $13.6 \mathrm{~g}$ on open beds (Table 3 ).

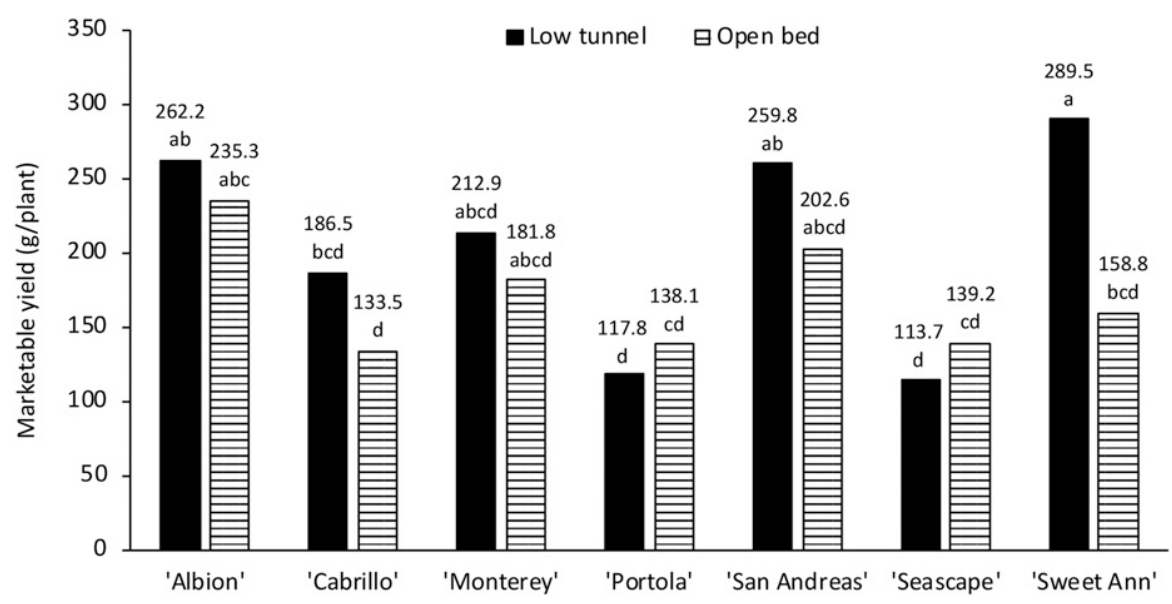

Fig. 2. Cover treatment and day-neutral strawberry cultivar effects on marketable yield at the University of New Hampshire in Durham in 2018. Low tunnels were covered by a $1.5-\mathrm{mil}(0.038 \mathrm{~mm})$ plastic. Plants were established on 7 May 2018 using dormant bare-rooted plants, grown on black plastic mulch, and harvested from 7 July through 1 Nov. 2018. Columns sharing a letter are not significantly different by Tukey's honestly significant difference test $(P \leq 0.05)(\mathrm{n}=4) ; 1 \mathrm{~g}=$ $0.0353 \mathrm{oz}$.

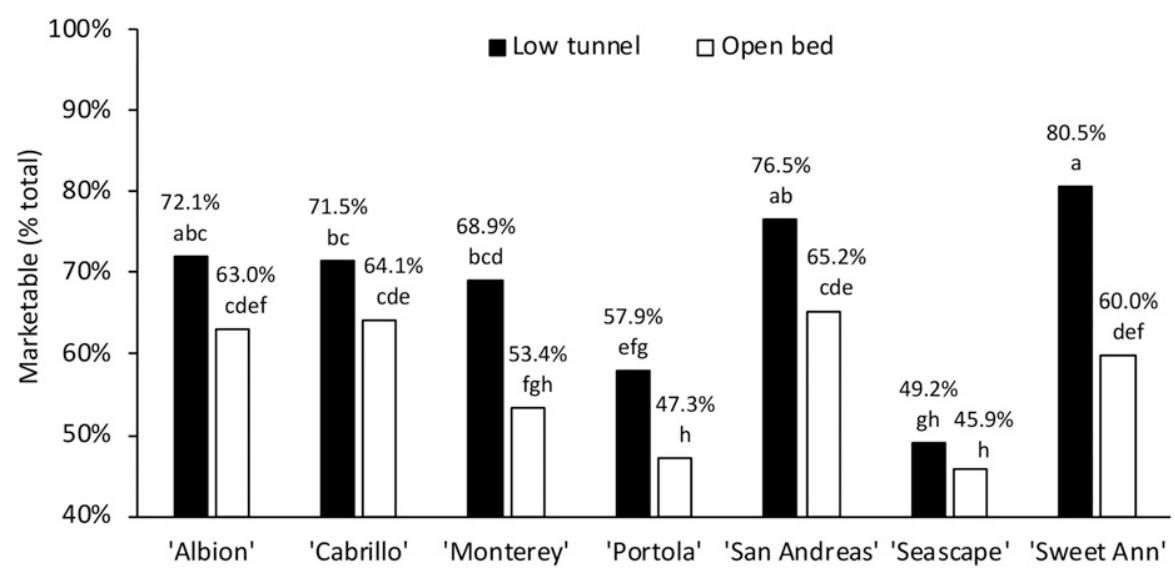

Fig. 3. Cover treatment and day-neutral strawberry cultivar effects on the percent marketable yield (by weight) at the University of New Hampshire in Durham in 2018. Low tunnels were covered by a $1.5-\mathrm{mil}(0.038 \mathrm{~mm})$ plastic. Plants were established on 7 May 2018 using dormant bare-rooted plants, grown on black plastic mulch, and harvested from 7 July through 1 Nov. 2018. Percent marketable yield was determined by dividing marketable yield by total yield (marketable + unmarketable). Fruit were considered unmarketable if they weighed less than $7.0 \mathrm{~g}$, or were damaged from contact with water, misshapen, covered by soil, or rotten. Columns sharing a letter are not significantly different by Tukey's honestly significant difference test $(P \leq 0.05)(n=4)$. 

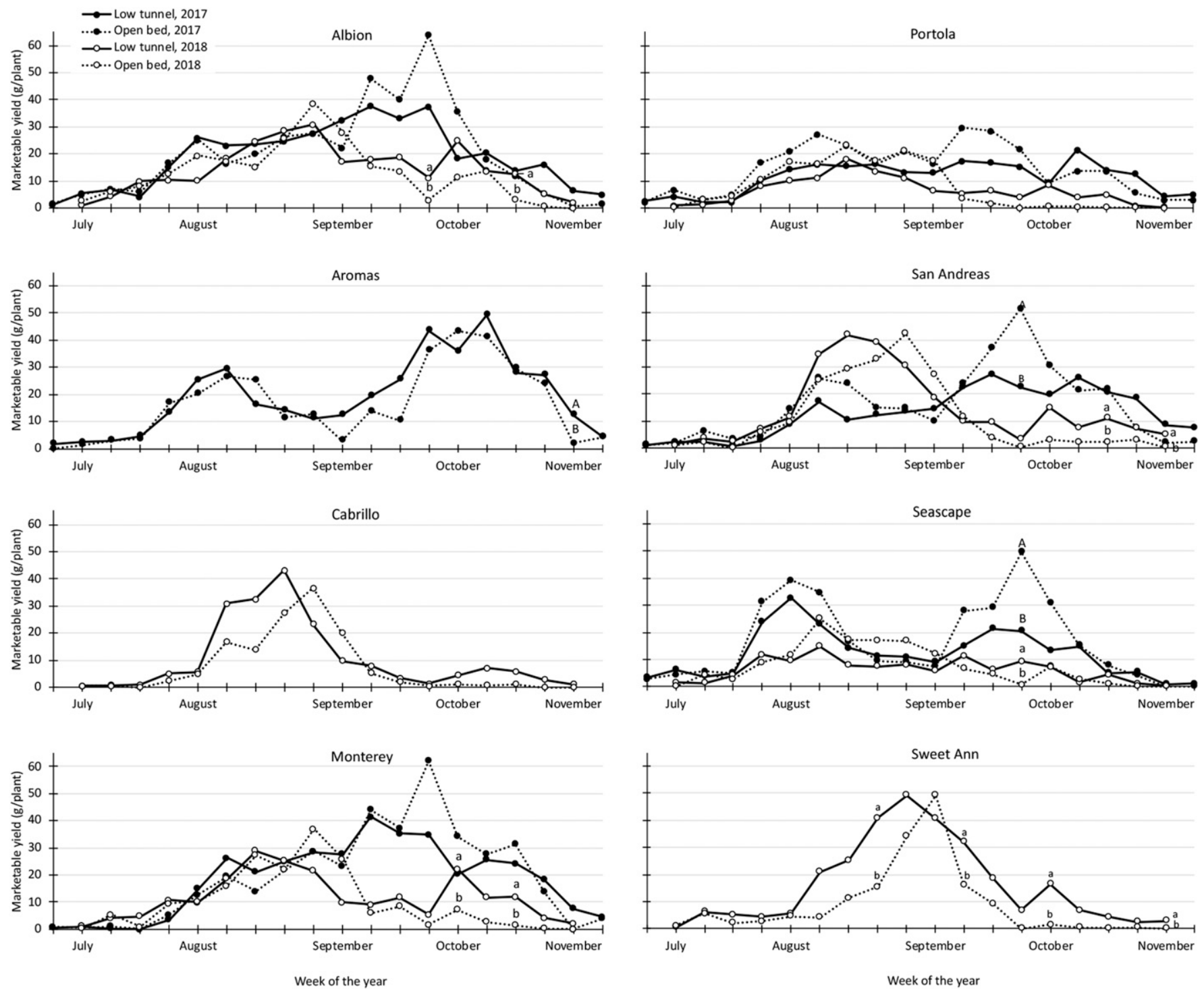

Fig. 4. Cover treatment effects on marketable yield of day-neutral strawberry cultivars at weekly intervals in 2017 and 2018 at the University of New Hampshire in Durham. Cover treatments were traditional open beds and low tunnels covered by 1.5 -mil $(0.038 \mathrm{~mm})$ plastic. Dormant bare-rooted strawberry plants were planted the spring of both years on $28 \mathrm{Apr} .2017$ and $7 \mathrm{May}$ 2018. Low tunnels sides were raised for the majority of the growing season, but were closed for rain and permanently closed on 31. Oct. 2017 and 1 Oct. 2018 (except for harvest). Mean separation letters are shown only for the weeks where a significant ( $P \leq 0.05$, Tukey's honestly significant difference test) difference in marketable yield existed between cover treatments. Uppercase means separation letters are for 2017, and lowercase are for $2018(\mathrm{n}=4) ; 1 \mathrm{~g}=0.0353 \mathrm{oz}$.

\section{SSC}

Cover treatment $(P=0.045$ in 2017 and $P=0.007$ in 2018$)$, cultivar $(P<0.0001)$, and sample date $(P<$ 0.0001 ) all influenced fruit SSC in both years (Table 4 ). A significant $(P=0.002)$ cover $\times$ date interaction occurred in 2017, due to the fact that the SSC was comparable between cover treatments at Date 1 and Date 2 , but significantly $(P \leq 0.05)$ greater under low tunnels on Date 3 (data not shown). In 2018, SSC was greater under low tunnels than open beds $[P \leq 0.05$ (Table 4)]. The cultivars Albion, Monterey, San Andreas, and
Seascape (and Sweet Ann in 2018) tended to have the greatest SSC.

\section{Runner emergence}

Cover $(P=0.010$ and $P=0.001$ in 2017 and 2018 , respectively) and cultivar $(P<0.0001)$ significantly influenced the cumulative number of runners produced per plant (data not shown), and a significant cover $\times$ cultivar interaction occurred in both years $(P=0.003$ and $P<0.0001$ in 2017 and 2018, respectively). Cultivars varied in their runner initiation from as few as 0.7 (low tunnel Seascape) to 20.3 per plant (open bed
Sweet Ann) (Fig. 5). All cultivars initiated fewer runners under low tunnels than open beds, but this effect was only significant $(P \leq 0.05)$ for Aromas, Monterey, and San Andreas in 2017, and Albion, Monterey, San Andreas, and Sweet Ann in 2018 (Fig. 5).

\section{Plant height and diameter}

Significant cover $\times$ cultivar, cover $\times$ date, and cultivar $\times$ date interactions occurred in both years for both height and diameter (with the exception of plant height in 2017, where the cover $\times$ date interaction was not significant) (Table 5). For plant height, 
Table 3. Cover and cultivar effects on the season-long average marketable fruit weight of eight day-neutral strawberry cultivars grown in separate experiments in 2017 and 2018 at the University of New Hampshire in Durham. Cover treatments were traditional open beds and low tunnels covered by $1.5-\mathrm{mil}$ $(0.038 \mathrm{~mm})$ plastic. Fruit weighing greater than $7.0 \mathrm{~g}$ were considered marketable. The average fruit weight was calculated at each harvest by dividing the marketable yield by the number of marketable fruit in each plot.

\begin{tabular}{|c|c|c|c|c|c|c|}
\hline \multirow[b]{3}{*}{ Treatment } & \multicolumn{6}{|c|}{ Marketable fruit wt $(\mathrm{g})^{\mathrm{z}}$} \\
\hline & \multicolumn{2}{|c|}{2017} & \multicolumn{4}{|c|}{2018} \\
\hline & Low tunnel & Open bed & Low & nnel & $\mathrm{Op}$ & bed \\
\hline Cover & 12.3 & 12.8 & 11.1 & & 12.4 & \\
\hline \multicolumn{7}{|l|}{ Cultivar } \\
\hline Albion & 13.1 & $a^{y}$ & 10.6 & defg & 12.1 & bcde \\
\hline Aromas & 12.8 & $\mathrm{a}$ & & & & \\
\hline Cabrillo & & & 11.6 & cdef & 12.2 & bcd \\
\hline Monterey & 13.5 & $\mathrm{a}$ & 10.6 & defg & 11.7 & bcdef \\
\hline Portola & 11.2 & $\mathrm{~b}$ & 10.2 & efg & 11.4 & cdefg \\
\hline San Andreas & 13.9 & $\mathrm{a}$ & 12.4 & bcd & 16.0 & a \\
\hline Seascape & 10.8 & $\mathrm{~b}$ & 9.5 & $\mathrm{~g}$ & 9.8 & fg \\
\hline Sweet Ann & & & 12.8 & bc & 13.6 & $\mathrm{~b}$ \\
\hline \multicolumn{7}{|l|}{ Significance } \\
\hline Cover & \multicolumn{2}{|c|}{0.123} & \multicolumn{4}{|c|}{0.003} \\
\hline Cultivar & \multicolumn{2}{|c|}{$<0.0001$} & \multicolumn{4}{|c|}{$<0.0001$} \\
\hline Cover $\times$ cultivar & \multicolumn{2}{|c|}{0.129} & \multicolumn{4}{|c|}{0.005} \\
\hline
\end{tabular}

${ }^{\mathrm{z}} 1 \mathrm{~g}=0.0353 \mathrm{oz}$.

y Within years, cultivar means followed by the same letter are not significantly different by Tukey's honestly significant difference test $(P \leq 0.05)$.

the cover $\times$ cultivar interaction was because while plants tended to be taller on open beds than under low tunnels, this difference was only significant $(P \leq 0.05)$ for three cultivars in each year (Aromas, Portola, and San Andreas in 2017; Monterey, Portola, and Seascape in 2018) (Table 6). Similarly, plant diameter tended to be greater on open beds, but was only significantly $(P \leq 0.05)$ so for 'Portola' in 2017, and 'Seascape' and 'Portola' in 2018 (Table 6).

The cover $\times$ date interaction for plant height and diameter was due to height and diameter being larger on open beds than under low tunnels during several, but not all, months (Fig. 6). However, in both years, plant height sharply decreased from September to November, when plant diameter increased (Fig. 6). This inverse relationship is likely directly related, as we observed that plants tended to slump over after frost.

Lastly, the cultivar $\times$ date interaction is illustrated in Fig. 7. 'Aromas' was the largest cultivar in 2017, with a height and diameter greater than most or all other cultivars in September and November $(P \leq 0.05)$ (Fig. 7). In 2018, 'Sweet Ann' had the largest plants, significantly $(P \leq 0.05)$ taller than all other cultivars except Cabrillo and San Andreas in September and November, respectively.

Diameter measurements collected in September showed that by this point in the season, no cultivar had reached the 16 -inch $(40.6 \mathrm{~cm})$ in-row plant spacing used in the study, though Aromas and San Andreas reached $37 \mathrm{~cm}$ in 2017 and 2018, respectively, and Sweet Ann had a diameter of $39 \mathrm{~cm}$ in Sept. 2018. By Nov. 2018, three cultivars reached 16 inches diameter: Cabrillo $(41 \mathrm{~cm})$, San Andreas $(43 \mathrm{~cm})$, and Sweet Ann $(45 \mathrm{~cm})$ (Fig. 7). The final diameter of 'Portola' was less than $30.5 \mathrm{~cm}$ in both years (Fig. 7).

Total yield was positively and moderately correlated with plant height $\left(R^{2}=0.25\right)$ and diameter $\left(R^{2}=0.48\right)$ under low tunnels, but was not strongly correlated with height and diameter on open beds $\left(R^{2}=0.005\right.$ and $R^{2}=0.05$, respectively) (data not shown). However, the total number of runners produced per plant positively correlated with plant height for low tunnels $\left(R^{2}=\right.$ $0.82)$ and open beds $\left(R^{2}=0.67\right)$, and for plant diameter for low tunnels $\left(R^{2}=0.60\right)$ and open beds $\left(R^{2}=\right.$ 0.58 ) (Fig. 4). We observed a steeper slope for both plant height and diameter on open beds.

\section{Temperature}

For soil temperature, cover treatment did not influence the seasonlong average, maximum, or minimum temperatures, but a significant cover $x$ month interaction for average and maximum soil temperature occurred $(P<0.008$ and $P<0.0001$, respectively) (Table 7 ). The maximum soil temperature interaction was due to a significantly $(P \leq 0.05)$ greater $\left(5.3{ }^{\circ} \mathrm{F}\right)$ maximum soil temperature under low tunnels than open beds during the month of October, when low tunnel sides were closed, but not during other months when low tunnels sides were open (Table 7).

For air temperature, season-long average $(P<0.0001)$, maximum $(P<$ $0.0001)$, and minimum $(P=0.017)$ temperatures were $1.3,4.2$, and 0.3 ${ }^{\circ} \mathrm{F}$ greater under low tunnels than open beds, respectively. However, a significant $(P<0.0001)$ cover $\times$ month interaction occurred for maximum air temperature because the average maximum air temperature was $3.1^{\circ} \mathrm{F}$ and $9.0^{\circ} \mathrm{F}$ greater under low tunnels in September and October, respectively (Table 7).

Even though low tunnels were almost entirely left open during the spring, summer, and early-fall, when sides were closed for precipitation on 14 Aug. 2018, air temperatures reached $104{ }^{\circ} \mathrm{F}$ inside low tunnels before they were opened again, 19.9 ${ }^{\circ} \mathrm{F}$ warmer than open beds (data not shown). During the month of October when low tunnel sides were closed permanently (except for harvest), the highest air temperatures occurred on 9 Oct. 2018, when the air temperature reached $92.3{ }^{\circ} \mathrm{F}$ under tunnels but remained $80.4^{\circ} \mathrm{F}$ on open beds (data not shown). The greatest temperature difference between the cover treatments in the fall occurred on 26 Oct. 2018, when the maximum air temperature was $19.9^{\circ} \mathrm{F}$ warmer under closed low tunnels than open beds (data not shown).

\section{Discussion}

DN cultivars produced strawberry fruit for between 18 and 20 consecutive weeks in both years of experiments, demonstrating that at our location, DN cultivars add a minimum of 4 months of strawberry production onto the existing 4- to 6-week season provided by short-day cultivars. At the plant density used in 
Table 4. Cover, cultivar, and sample date effects on the percent soluble solids content (SSC) of day-neutral strawberry fruit at three similar dates in 2017 and 2018. Cover treatments were traditional open beds and low tunnels covered by 1.5-mil (0.038 mm) plastic. Sample dates were as follows: Date $1=1$ Aug. 2017 and 6 Aug. 2018; Date 2 = 25 Aug. 2017 and 24 Aug. 2018; Date 3 = 6 Oct. 2017 and 1 Oct. 2018. The SSC was measured individually on 10 fruit (or the available quantity) from each plot, and the 10 measurements were averaged to determine a mean SSC value for that plot.

\begin{tabular}{|c|c|c|c|c|}
\hline \multirow[b]{2}{*}{ Treatment } & \multicolumn{4}{|c|}{ Mean SSC (\%) } \\
\hline & \multicolumn{2}{|l|}{2017} & \multicolumn{2}{|l|}{2018} \\
\hline \multicolumn{5}{|l|}{ Cover } \\
\hline Low tunnel & 10.5 & & 9.5 & $a^{z}$ \\
\hline Open bed & 9.7 & & 8.5 & $\mathrm{~b}$ \\
\hline \multicolumn{5}{|l|}{ Cultivar } \\
\hline Albion & 10.6 & $a b^{y}$ & 9.5 & $\mathrm{a}$ \\
\hline Aromas & 9.2 & $\mathrm{c}$ & & \\
\hline Cabrillo & & & 8.1 & $\mathrm{~b}$ \\
\hline Monterey & 11.3 & a & 9.3 & $\mathrm{a}$ \\
\hline Portola & 8.6 & c & 7.7 & $\mathrm{~b}$ \\
\hline San Andreas & 10.0 & $b$ & 9.2 & $\mathrm{a}$ \\
\hline Seascape & 10.6 & $b$ & 9.5 & $\mathrm{a}$ \\
\hline Sweet Ann & & & 9.4 & $\mathrm{a}$ \\
\hline \multicolumn{5}{|l|}{ Sample date } \\
\hline Date 1, early-August & 10.8 & & 7.8 & $\mathrm{c}$ \\
\hline Date 2 , late-August & 9.0 & & 8.7 & $\mathrm{~b}$ \\
\hline Date 3, early-October & 10.4 & & 10.3 & $\mathrm{a}$ \\
\hline \multicolumn{5}{|l|}{ Significance } \\
\hline Cover & 0.045 & & 0.007 & \\
\hline Cultivar & $<0.0001$ & & $<0.0001$ & \\
\hline Sample date & $<0.0001$ & & $<0.0001$ & \\
\hline Cover $\times$ cultivar & 0.180 & & 0.122 & \\
\hline Cover $\times$ sample date & 0.002 & & 0.622 & \\
\hline Cultivar $\times$ date & 0.106 & & 0.126 & \\
\hline Cover $\times$ cultivar $\times$ sample date & 0.882 & & 0.543 & \\
\hline
\end{tabular}

${ }^{\mathrm{z}}$ Within year, cover means followed by the same letter are not significantly different by Student's $t$ test $(P \leq 0.05)$. 'Within year, cultivar or sample date means followed by the same letter are not significantly different by Tukey's honestly significant difference test $(P \leq 0.05)$.

this study of 13,068 plants/acre (based on 16-inch in-row spacing and standard 5 - $\mathrm{ft}$ bed centers), annual marketable yield in 2017 ranged from
$8228 \mathrm{~kg} \cdot \mathrm{ha}^{-1}$ for 'Portola' to 12,565 $\mathrm{kg} \cdot \mathrm{ha}^{-1}$ for 'Albion', with three of the six cultivars (Albion, Aromas, and Monterey) producing greater than
11,209 $\mathrm{kg} \cdot \mathrm{ha}^{-1}$. Marketable yields were lower in 2018 than 2017 , and ranged from $3672 \mathrm{~kg} \cdot \mathrm{ha}^{-1}$ for low tunnel 'Seascape' to $9349 \mathrm{~kg} \cdot \mathrm{ha}^{-1}$ for low tunnel 'Sweet Ann'. We attribute lower yields in 2018 to frequent rainfall and poor growing conditions in September and October, when water directly damaged fruit and the moisture encouraged the spread of fruit anthracnose, especially on the open beds. Strawberry plants were also established later in 2018 than in 2017, and later planting (even by a few weeks) has resulted in lower annual yields in other studies (Pritts and McDermott, 2017; Weber et al., 2018). Since year, site, and planting date have influenced yield in other experiments with low tunnels (Petran et al., 2016; Weber et al., 2018) and it is well established that strawberry plants are influenced by the complex interactions between cultivar and growing season, location, soil type, and production system (Galletta and Bringhurst, 1990), the yield differential we observed between years does not appear to be unique to our location. It does, however, illustrate the potential fluctuations in production that commercial growers experience.

The annual marketable yields reported in this study are lower than what would be acceptable in some regions of the country (e.g., California), but generally meet or exceed the $5900 \mathrm{lb} /$ acre New England growers report harvesting each year from short-day cultivars (U.S. Department of Agriculture National Agricultural

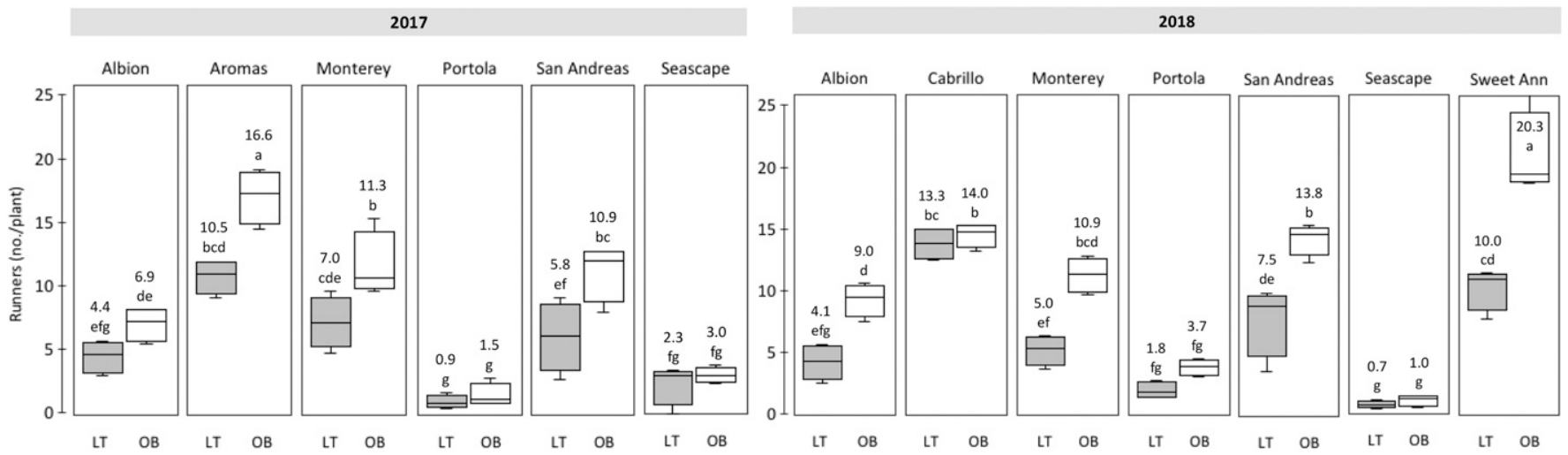

Fig. 5. Cover and cultivar effects on the total number of runners produced per day-neutral strawberry plant during the 2017 and 2018 growing seasons at the University of New Hampshire in Durham. Cover treatments were traditional open beds (OB) and low tunnels (LT) covered by $1.5-\mathrm{mil}(0.038 \mathrm{~mm})$ plastic. The mean number of runners produced per plant is shown above each box. Boxes illustrate the distribution in the total number of runners produced per plant across experimental units, with half the data points falling within the box, and whiskers reaching to the maximum and minimum total number of runners. Horizontal lines within boxes indicate the median number of total runners produced per plant of the four experimental units. Within year, boxes sharing a letter are not significantly different (Tukey's honestly significant difference test; $P \leq 0.05)(n=4)$. 
Statistics Service, 2018). This strongly suggests that DN production is not only feasible in New England, but that DN cultivars can produce very competitive yields.

The in-row plant spacing used in this experiment (16 inches) is recommended for high vigor cultivars and sites (Lantz et al., 2010) and was selected to accommodate any such cultivars in our study. However, this spacing is more expansive than some recommendations (Handley, 2008, 2017; Pritts, 2017b; Pritts and McDermott, 2017) and 'Aromas', 'San Andreas', and 'Sweet Ann' were the only cultivars to come close to reaching 16 inches in diameter by September. Therefore, to optimize bed area and increase per acre yield, we believe the following distances are a sufficient baseline in-row plant spacing for cultivars: 12 inches for 'Portola', 14 inches for 'Albion', 'Cabrillo', 'Monterey', and 'Seascape', and 16 inches for 'Aromas', 'San Andreas', and 'Sweet Ann'. Furthermore, field studies show that per acre yields increase when plants are at a high density, even if per plant yield decreases (Legard et al., 2000; Pérez De Camacaro et al., 2004).

\section{Cover treatment on yield}

Aside from 'Sweet Ann' in 2018, low tunnels did not impact season-long marketable or total yield in either year of our experiment, a finding that agrees with studies conducted in Minnesota (Petran et al., 2016) and in 1 of 2 years in Quebec, Canada (Van Sterthem

Table 5. Cover, cultivar, and date effects on plant height and diameter for dayneutral strawberry plants grown on black plastic mulch at the University of New Hampshire in Durham in 2017 and 2018. Cover treatments were traditional open beds and low tunnels covered by $1.5-\mathrm{mil}(0.038 \mathrm{~mm})$ plastic. Cultivars were: Albion, Aromas, Cabrillo, Monterey, Portola, San Andreas, Seascape, and Sweet Ann. The dates measurements were collected were: 5 Sept. and 15 Nov. 2017, and 13 July, 16 Aug., 19 Sept., and 12 Nov. 2018.

\begin{tabular}{lccccc}
\hline & \multicolumn{2}{c}{$\mathbf{H t}^{\mathrm{z}}$} & & \multicolumn{2}{c}{ Diam $^{\mathrm{y}}$} \\
\cline { 2 - 3 } \cline { 5 - 6 } Significance & $\mathbf{2 0 1 7}$ & $\mathbf{2 0 1 8}$ & & $\mathbf{2 0 1 7}$ & $\mathbf{2 0 1 8}$ \\
\hline Cover & 0.004 & 0.030 & & 0.051 & 0.034 \\
Cultivar & $<0.0001$ & $<0.0001$ & & $<0.0001$ & $<0.0001$ \\
Date & $<0.0001$ & $<0.0001$ & & $<0.0001$ & $<0.0001$ \\
Cover $\times$ cultivar & 0.031 & 0.039 & & 0.028 & 0.008 \\
Cover $\times$ date & 0.111 & $<0.0001$ & & 0.014 & $<0.001$ \\
Cultivar $\times$ date & 0.049 & 0.002 & & 0.011 & $<0.001$ \\
Cover $\times$ cultivar $\times$ date & 0.753 & 0.298 & & 0.383 & 0.828 \\
\hline
\end{tabular}

${ }^{\mathrm{z}}$ Plant height was determined by measuring from base of the plant to the tallest point of living foliage (including flower trusses).

${ }^{y}$ Plant diameter was measured parallel to the edge of the raised bed and included living foliage and flower trusses.

Table 6. Cover and cultivar effects on the season-long average plant height and diameter of day-neutral strawberry cultivars 2017 and 2018 at the University of New Hampshire in Durham. Cover treatments were traditional open beds and low tunnels covered by $1.5-\mathrm{mil}(0.038 \mathrm{~mm})$ plastic. Measurements were made on 5 Sept. and 15 Nov. 2017 , and 13 July, 16 Aug., 19 Sept., and 12 Nov. 2018, and are an average of all dates and do not represent final plant size $(n=4)$.

\begin{tabular}{|c|c|c|c|c|c|c|c|c|c|}
\hline \multirow[b]{2}{*}{ Plant ht ${ }^{\mathrm{y}}$} & & \multicolumn{8}{|c|}{ Plant size $(\mathrm{cm})^{\mathrm{z}}$} \\
\hline & & Albion & Aromas & Cabrillo & Monterey & Portola & San Andreas & Seascape & Sweet Ann \\
\hline 2017 & Low tunnel & $15 \mathrm{efg}^{\mathrm{x}}$ & $21 \mathrm{~b}$ & & $19 \mathrm{bcd}$ & $13 \mathrm{~g}$ & $16 \mathrm{def}$ & $14 \mathrm{fg}$ & \\
\hline \multirow[t]{2}{*}{2018} & Low tunnel & $16 \mathrm{gh}$ & & 19 bcdef & $17 \mathrm{efg}$ & $13 \mathrm{i}$ & $18 \mathrm{cefg}$ & $13 \mathrm{hi}$ & $21 \mathrm{abd}$ \\
\hline & Open bed & $18 \mathrm{defg}$ & & 20 abcde & $21 \mathrm{abc}$ & $17 \mathrm{fgh}$ & 20 abcde & $17 \mathrm{fg}$ & $22 \mathrm{a}$ \\
\hline
\end{tabular}

Plant diameter ${ }^{\mathrm{w}}$

\begin{tabular}{|c|c|c|c|c|c|c|c|c|c|}
\hline \multirow[t]{2}{*}{2017} & Low tunnel & 32 bcde & $36 \mathrm{abc}$ & & $32 \mathrm{de}$ & $25 \mathrm{f}$ & $32 \mathrm{de}$ & $31 \mathrm{e}$ & \\
\hline & Open bed & 33 ce & 39 a & & $37 \mathrm{abd}$ & $31 \mathrm{e}$ & 34 bcde & 34 bcde & \\
\hline \multirow[t]{2}{*}{2018} & Low tunnel & $30 \mathrm{cdef}$ & & $32 \mathrm{abcd}$ & $30 \mathrm{def}$ & $23 \mathrm{~g}$ & $34 \mathrm{abc}$ & $27 \mathrm{f}$ & $35 \mathrm{ab}$ \\
\hline & Open bed & 31 bcdef & & $34 \mathrm{abcd}$ & $34 \mathrm{abcd}$ & $29 \mathrm{ef}$ & $36 a$ & 32 bcde & $36 \mathrm{a}$ \\
\hline
\end{tabular}

${ }^{\mathrm{z}} 1 \mathrm{~cm}=0.3937$ inch

${ }^{y}$ Plant height was determined by measuring from base of the plant to the tallest point of living foliage (including flower trusses).

${ }^{\mathrm{x}}$ Within variable (height or diameter) and year, cultivar means sharing letters are not significantly different by Tukey's honestly significant difference test $(P \leq 0.05)$.

wPlant diameter was measured parallel to the edge of the raised bed and included living foliage and flower trusses. 

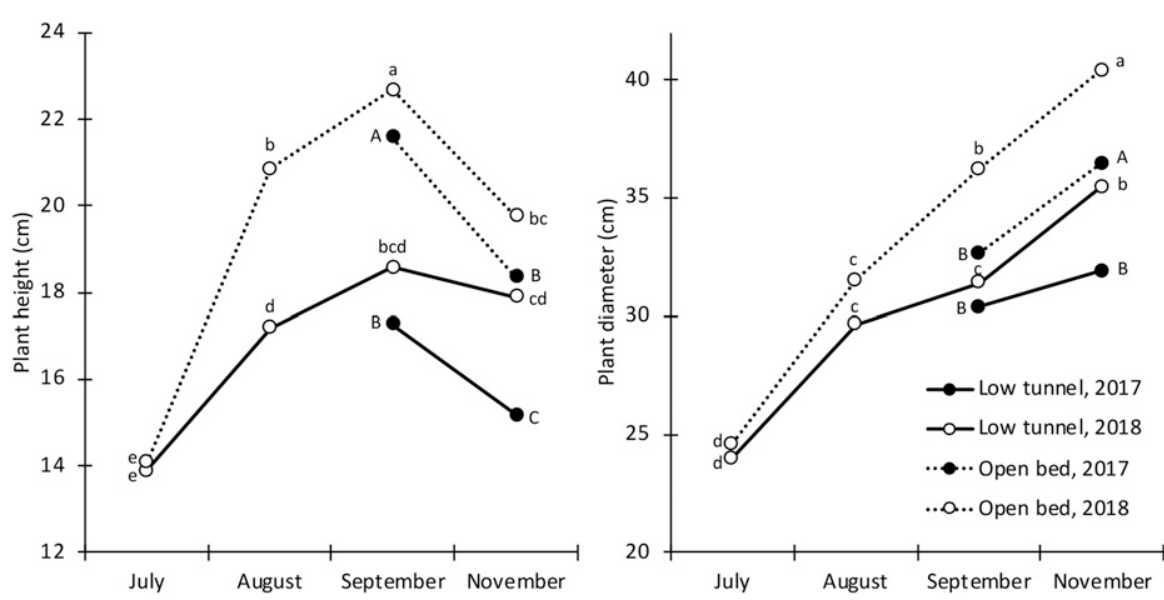

Fig. 6. Cover effects on the height and diameter of day-neutral strawberry cultivars over the course of the growing season at the University of New Hampshire in Durham. Values are an average of all cultivars in each year (2017: Albion, Aromas, Monterey, Portola, San Andreas, and Seascape; 2018: Albion, Cabrillo, Monterey, Portola, San Andreas, Seascape, and Sweet Ann). Cover treatments were traditional open beds and low tunnels covered by $1.5-\mathrm{mil}(0.038 \mathrm{~mm})$ plastic. Labels refer to the month in which measurements were collected. The exact dates were 5 Sept. and 15 Nov. 2017, and 13 July, 16 Aug., 19 Sept., and 12 Nov. 2018. Plant height was determined by measuring from base of the plant to the tallest point of living foliage (including flower trusses). Plant diameter was measured parallel to the edge of the raised bed and also included living foliage and flower trusses. Within year, data points sharing a letter are not significantly different (Tukey's honestly significant difference test; $P \leq 0.05$ ). Uppercase mean separation letters refer to 2017 , and lowercase to $2018(n=24$ in 2017 , and $n=28$ in 2018); $1 \mathrm{~cm}=0.3937$ inch.

\section{Cultivar yield}

The differences in fruiting patterns that we observed among cultivars illustrates that $\mathrm{DN}$ cultivars vary in their fruiting patterns and suggests that a combination of early, mid, and late-season cultivars may be necessary to produce a consistent supply of fruit from early-summer through late-fall in our region.

The cumulative marketable yield of 'Albion', 'Monterey', 'Portola', 'San Andreas', and 'Seascape' mostly fell within the yield range reported for the same cultivars in Minnesota (Petran et al., 2016), and in 2017, the marketable yield of Seascape was nearly identical to yield of the same cultivar in Quebec, Canada (Van Sterthem et al., 2017). However, marketable yields of 'Albion' and 'Seascape' were low in our experiment compared with those reported for New York, where Weber et al., (2018) harvested an average of $525 \mathrm{~g} /$ plant per plant from under low tunnels.

Low tunnel 'Sweet Ann' stood out in 2018 for producing the greatest marketable yields, more than 'Albion', which had the greatest marketable yields the previous year, suggesting that
'Sweet Ann' may be a good fit for northeastern U.S. production. Given that 'Sweet Ann' produced substantially greater marketable yields under low tunnels than open beds in 2018 ( $130.7 \mathrm{~g} /$ plant more), the cultivar may be better suited for protected culture.

'Aromas' has not been included in most other experiments evaluating DNs, but was the third highest yielding cultivar in our 2017 experiment, producing $354 \mathrm{~g} /$ plant. This yield was nearly identical to that reported for field production in North Carolina, where the cultivar produced 358 g/plant (Ballington et al., 2008). Interestingly, the cultivar is currently difficult to obtain and has not been popular in key strawberry producing regions of the United States, but is very popular in Brazil, Chile, and Peru (Kirschbaum et al., 2017). With marketable yields similar to 'Albion' in 2017, we believe that 'Aromas' may be a cultivar worth reconsidering for the northeastern United States.

'Portola' and 'Seascape' produced the lowest marketable yields in both years of experiments. Interestingly, 'Portola' has produced very high yields elsewhere (Lewers et al., 2017;
Petran et al., 2016; Pritts, 2017a), but the cultivar did not establish well at our site in either year, remaining small and stunted throughout the season. Conversely, 'Seascape' plants were very healthy, especially early season, but produced a high proportion of small unmarketable fruit.

\section{SSC}

Few studies have investigated the effects of low tunnels on SSC and existing results are mixed, with Petran et al. (2016) reporting no difference in SSC between open beds and low tunnels, and Resende et al. (2010) finding low tunnels increased fruit SSC. In larger structures, results are also mixed, but several experiments have reported an increase in SSC under protected culture compared with open beds (Salamé-Donoso et al., 2010; Voća et al., 2007). Our results showing greater SSC under low tunnels in Oct. 2017 and all three dates in 2018 is in agreement with experiments finding protected culture increases SSC.

Both temperature and crop load have previously been shown to affect strawberry fruit SSC (Correia et al., 2011; Ruan et al., 2013; Wang and Camp, 2000). In our experiments, SSC tended to increase as the season progressed and be higher in the fall than the summer. This outcome is in agreement with work attributing late-season peaks in SSC to cooler temperatures (Ruan et al., 2013). Furthermore, temperature increases have been shown to reduce sugar content (Wang and Camp, 2000). Therefore, we suggest the low SSC values recorded in August may be due to high temperatures and a greater fruit load, especially of developing fruit. Low average SSC during the month of August has also been noted by others (Petran et al., 2016; Ruan et al., 2013).

Variation in SSC among cultivars is well-established (Petran et al., 2016; Pistón et al., 2017; Ruan et al., 2013), and our results that Albion, Monterey, San Andreas, and Seascape tend to have greater SSC, especially compared with 'Portola', is similar to other findings (Capocasa et al., 2017; Petran et al., 2016; Ruan et al., 2013). However, while 'Albion' is often regarded as having an unsurpassed eating quality due to its high sugar content and firm fruit (Ruan et al., 2013), we found that fully ripe 'Monterey', 'San Andreas', 

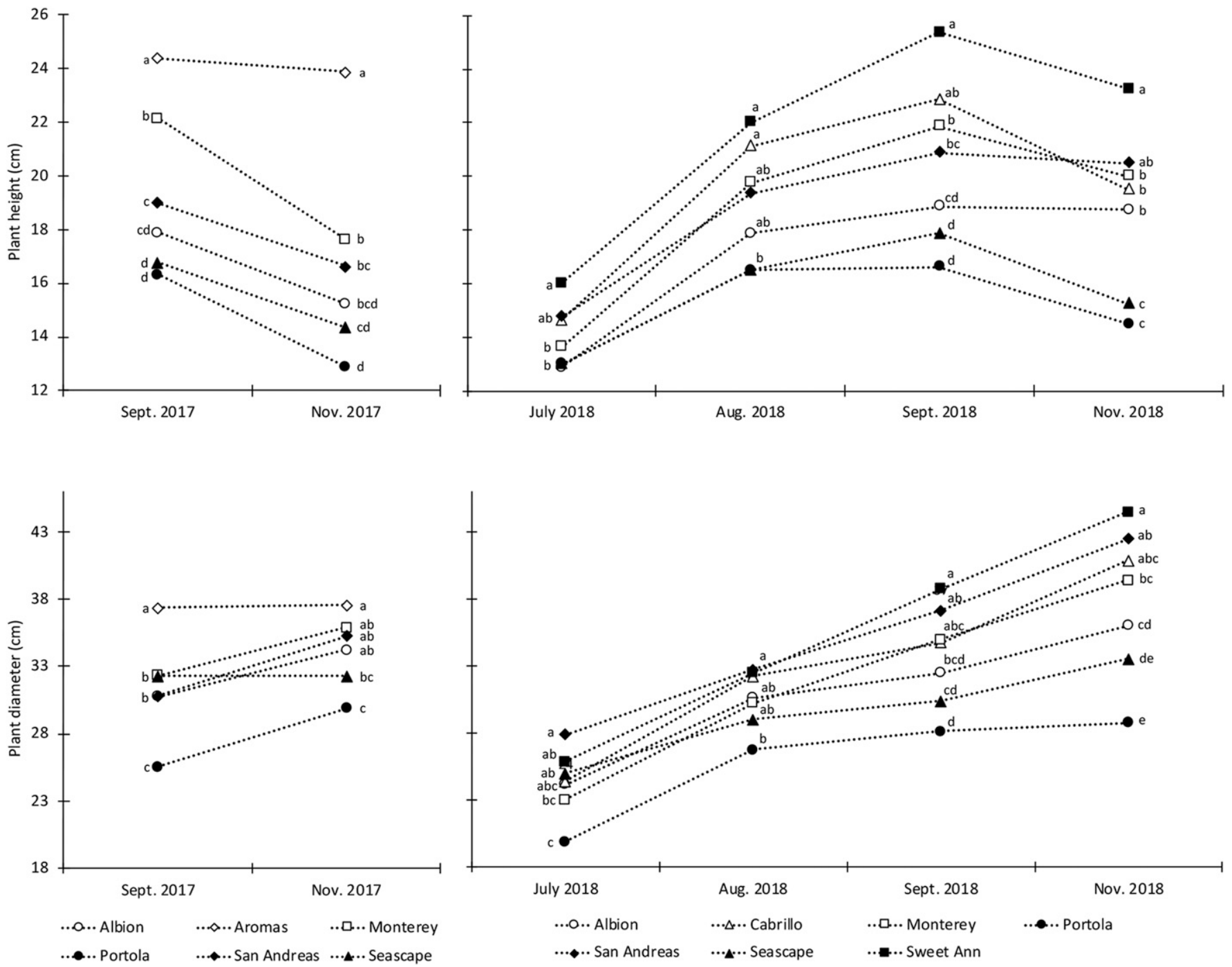

Fig. 7. Cultivar and date effects on the height and diameter of day-neutral strawberry cultivars grown at the University of New Hampshire in Durham in 2017 and 2018. Values are an average of both cover treatments (open beds and low tunnels). Labels refer to the month in which measurements were collected. The exact dates were 5 Sept. and 15 Nov. 2017 , and 13 July, 16 Aug., 19 Sept., and 12 Nov. 2018. Within year and month, cultivars sharing a letter are not significantly different (Tukey's honestly significant difference test; $P \leq \mathbf{0 . 0 5}$ ). Plant height was determined by measuring from the base of the plant to the tallest point of living foliage (including flower trusses). Plant diameter was measured parallel to the edge of the raised bed and included living foliage and flower trusses $(\mathrm{n}=8) ; 1 \mathrm{~cm}=0.3937 \mathrm{inch}$.

'Seascape', and 'Sweet Ann' had quantitatively and qualitatively comparable eating qualities to 'Albion'. Compared with other published experiments using the same cultivars (Petran et al., 2016; Ruan et al., 2013), SSC was high in our experiments. In fact, even the cultivar with the lowest SSC in our study, Portola, had a greater or similar SSC to Monterey, San Andreas, and Seascape in other experiments (Capocasa et al., 2017; Petran et al., 2016; Ruan et al., 2013).

\section{Runner initiation and plant size}

Our results showing a reduction in runner initiation under low tunnels supports the early observation made Lewers (2013) that plants initiated fewer runners under low tunnels than open beds. However, we found this outcome was only the case for the cultivars which produced the greatest number of runners (Aromas, Monterey, San Andreas, and Sweet Ann). For these cultivars, low tunnels reduced runner initiation by $37 \%$ to $54 \%$. 'Sweet Ann', in particular, initiated 10.3 fewer runners per plant under low tunnels than on open beds. This outcome strongly suggests that for certain cultivars, labor requirements for runner removal may be reduced if plants are grown under low tunnels.
Both temperature and plant size are possible explanations for the reduction in runner initiation under low tunnels. Previous work has shown that temperature plays a key role in runner development (Galletta and Bringhurst, 1990), with Durner et al. (1984) demonstrating that runner emergence more than doubled when day/night temperatures increased from $18 / 14$ to $26 / 22{ }^{\circ} \mathrm{C}$. However, in our experiment, temperatures on open beds were either comparable to low tunnels or slightly cooler; therefore, it does not appear that temperature was the driver of increased runner production on open beds. 
Table 7. Cover treatment and month effects on air and soil temperatures during the 2018 growing season at the University of New Hampshire in Durham. Temperatures are for the period of 10 July 2018 through 31 Oct. 2018. Cover treatments were traditional open beds and low tunnels covered by $1.5-\mathrm{mil}(0.038 \mathrm{~mm})$ plastic. Low tunnels sides were raised for the majority of the growing season, but were periodically closed for rain and permanently closed (except for harvest) on 1 Oct. 2018. Temperatures were recorded using outdoor temperature sensors (Hobo U12-008 4-channel logger; Onset Computer Corp., Bourne, MA) $(\mathrm{n}=4)$.

\begin{tabular}{|c|c|c|c|c|c|c|c|c|c|c|c|c|}
\hline \multirow[b]{3}{*}{$\begin{array}{l}\text { Cover } \\
\text { treatment }\end{array}$} & \multicolumn{6}{|c|}{ Soil temp $\left({ }^{\circ} \mathbf{F}\right)^{\mathrm{z}}$} & \multicolumn{6}{|c|}{ Air temp $\left({ }^{\circ} \mathbf{F}\right)^{y}$} \\
\hline & \multicolumn{2}{|c|}{ Avg } & \multicolumn{2}{|c|}{ Maximum } & \multicolumn{2}{|c|}{ Minimum } & \multicolumn{2}{|c|}{ Avg } & \multicolumn{2}{|c|}{ Maximum } & \multicolumn{2}{|c|}{ Minimum } \\
\hline & $\begin{array}{c}\text { Low } \\
\text { tunnel }\end{array}$ & $\begin{array}{c}\text { Open } \\
\text { bed }\end{array}$ & $\begin{array}{c}\text { Low } \\
\text { tunnel }\end{array}$ & $\begin{array}{c}\text { Open } \\
\text { bed }\end{array}$ & $\begin{array}{c}\text { Low } \\
\text { tunnel }\end{array}$ & $\begin{array}{c}\text { Open } \\
\text { bed }\end{array}$ & $\begin{array}{c}\text { Low } \\
\text { tunnel }\end{array}$ & $\begin{array}{c}\text { Open } \\
\text { bed }\end{array}$ & $\begin{array}{c}\text { Low } \\
\text { tunnel }\end{array}$ & $\begin{array}{c}\text { Open } \\
\text { bed }\end{array}$ & $\begin{array}{c}\text { Low } \\
\text { tunnel }\end{array}$ & $\begin{array}{c}\text { Open } \\
\text { bed }\end{array}$ \\
\hline \multicolumn{13}{|l|}{ Month } \\
\hline July & $82.4 \mathrm{ab}^{\mathrm{x}}$ & $81.6 \mathrm{a}$ & $94.4 \mathrm{ab}$ & $95.5 \mathrm{a}$ & $73.4 \mathrm{a}$ & $71.5 \mathrm{ab}$ & $72.5 \mathrm{a}$ & $71.5 \mathrm{a}$ & 86.9 a & $84.3 \mathrm{a}$ & $61.0 \mathrm{a}$ & $60.7 \mathrm{a}$ \\
\hline August & $81.4 \mathrm{ab}$ & $79.1 \mathrm{~b}$ & $91.5 \mathrm{ab}$ & $90.3 \mathrm{~b}$ & $74.1 \mathrm{a}$ & $71.4 \mathrm{ab}$ & $73.4 \mathrm{a}$ & $72.5 \mathrm{a}$ & $86.1 \mathrm{a}$ & $84.1 \mathrm{a}$ & $63.2 \mathrm{a}$ & $62.7 \mathrm{a}$ \\
\hline Season avg ${ }^{w}$ & 72.8 & 70.0 & 82.0 & 79.7 & 66.2 & 63.2 & $65.1 \mathrm{~A}$ & $63.8 \mathrm{~B}$ & $79.4 \mathrm{~A}$ & $75.2 \mathrm{~B}$ & $54.4 \mathrm{~A}$ & $54.1 \mathrm{~B}$ \\
\hline \multicolumn{13}{|l|}{ Significance } \\
\hline Cover & \multicolumn{2}{|c|}{0.243} & \multicolumn{2}{|c|}{0.214} & \multicolumn{2}{|c|}{0.283} & \multicolumn{2}{|c|}{$<0.0001$} & \multicolumn{2}{|c|}{$<0.0001$} & \multicolumn{2}{|c|}{0.017} \\
\hline Month & \multicolumn{2}{|c|}{$<0.0001$} & \multicolumn{2}{|c|}{$<0.0001$} & \multicolumn{2}{|c|}{$<0.0001$} & \multicolumn{2}{|c|}{$<0.0001$} & \multicolumn{2}{|c|}{$<0.0001$} & \multicolumn{2}{|c|}{$<0.0001$} \\
\hline
\end{tabular}

${ }^{\mathrm{z}}$ Soil temperatures were collected at a soil depth of 3 inches $(7.6 \mathrm{~cm})$ under 1.25 -mil $(0.032 \mathrm{~mm})$ black plastic mulch; $\left({ }^{\circ} \mathrm{F}-32\right) \div 1.8={ }^{\circ} \mathrm{C}$.

${ }^{y}$ Air temperatures were collected under a solar radiation shield placed 12 inches $(30.5 \mathrm{~cm})$ above bed height.

${ }^{\mathrm{x}}$ Within average, maximum, or minimum columns, means sharing a lowercase letter (across all mo. and both cover treatments) are not significantly different (Tukey's honestly significant difference test; $P \leq 0.05$ ).

"Within average, maximum, or minimum columns, LT and OB season averages sharing an uppercase letter are not significantly different (Student's $t$ test; $P \leq 0.05)$.
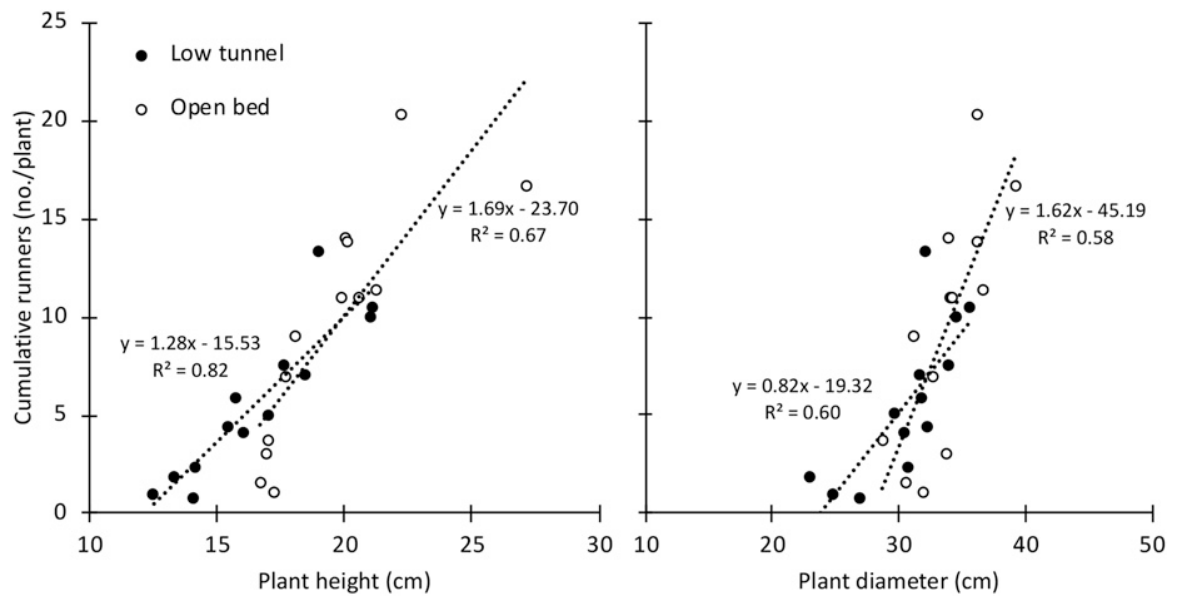

Fig. 8. Relationship between the total number of runners produced per plant and the average plant height or diameter of day-neutral strawberry cultivars grown at the University of New Hampshire in Durham in 2017 and 2018. Cultivars are not distinguished from each other. There are two data points on each graph for cultivars that were in both years of experiments (Albion, Monterey, Portola, San Andreas, and Seascape) and one data point for cultivars included in one experiment only (Aromas, Cabrillo, and Sweet Ann) $(\mathrm{n}=4) ; 1 \mathrm{~cm}=0.3937$ inch.

A larger plant volume (size), has been positively correlated with crown and runner dry weights in the past (Galletta and Bringhurst, 1990; Nicoll and Galletta, 1987). We found that on open beds, where plants often produced a greater number of runners, plants were consistently taller than under low tunnels in the month of September, and in 1 of 2 years, in
August and November. Interestingly, we recorded a stronger relationship between runner emergence and plant size under low tunnels than on open beds, but show a steeper slope in the relationship for open beds (Fig. 8). This indicates that for a fixed increase in plant height or diameter, there was a stronger response of runner initiation on open beds than under low tunnels.
It is unclear why plants showed a trend of being smaller under low tunnels, but Condori et al. (2017) reported measuring a $33 \%$ reduction in photosynthetically active radiation $(P A R)$ under low tunnels in Maryland, where low tunnels were covered with a 4-mil-thick film (Condori et al., 2017). The thinner 1.5-mil film used in our study has also been found to reduce $P A R$, but only by $7 \%$ to $10 \%$ (M. Cooper and K. Demchak, unpublished data); thus, it is unlikely that $P A R$ transmission was reduced by more than $10 \%$ in our study. However, since irradiance $\left(\mu \mathrm{mol} \cdot \mathrm{m}^{-2} \cdot \mathrm{s}^{-1}\right)$ may have been slightly reduced and the photosynthetic rate in plants depends on photon absorption (Nobel, 2005), it is possible that plant growth could have been constrained under low tunnels, especially given that shading can reduce the photosynthetic rate of strawberry (Chi et al., 2001; Tabatabaei et al., 2008). Typically, increased shading results in a shade avoidance response where stems elongate and plant height increases (Schmitt and Wulff, 1993; Takaichi et al., 2000), but in strawberry, a reduction in fresh and dry leaf weight, leaf area, and leaf and crown initiation has been reported under shaded conditions (Awang and Atherton; 1995; Tabatabaei et al., 2008). 


\section{Temperature}

Season-long air temperatures, but not soil temperatures, were significantly increased by low tunnels in our study. The $1.3^{\circ} \mathrm{F}$ increase in average air temperature we measured is comparable to average increases in other studies (Condori et al., 2017; Van Sterthem et al., 2017). Interestingly, while our data show that season-long minimum air temperatures were also significantly warmer under low tunnels, the increase was only $0.3{ }^{\circ} \mathrm{F}$, and as the season progressed into the fall months, low tunnels and open beds had increasingly similar minimum temperatures. This suggests that while low tunnels block wind and may influence humidity levels (Condori et al., 2017; A. Petran, personal communication), they do not appear to provide thermal insulation during the colder fall months. This outcome is similar to what has been observed in high tunnels, which often reach the same nighttime minimum air temperature as unprotected environments, especially during the colder months (Wein, 2009).

The most significant temperature differences between cover treatments occurred when low tunnel sides were lowered for rain and during the month of October. In October, maximum temperatures were substantially greater under low tunnels than open beds, by an average of 5.3 ${ }^{\circ} \mathrm{F}$ (air) and $9{ }^{\circ} \mathrm{F}$ (soil). This effect suggests that season-long temperature averages obscure the effects of ventilation practices on daily fluctuations in temperature, which can become quite warm under closed tunnels. In fact, temperatures reached at high as $104.0^{\circ} \mathrm{F}$ under low tunnels in August, and up to $92.3^{\circ} \mathrm{F}$ under closed low tunnels in October in our study. On both occasions, temperatures were substantially greater under low tunnels than open beds, by as much as $19.9^{\circ} \mathrm{F}$. Since flowering in strawberry can be reduced at temperatures exceeding $30 / 25{ }^{\circ} \mathrm{C}$ day/ night $\left(86.0 / 77.0{ }^{\circ} \mathrm{F}\right)$ (Durner et al., 1984; Kadir et al., 2006; Ledesma et al., 2008), and even brief exposure to $42{ }^{\circ} \mathrm{C}\left(107.6{ }^{\circ} \mathrm{F}\right)$ can negatively influence fruit set (Ledesma and Kawabata, 2016), careful ventilation management needs to be a key component of low tunnel strawberry production. Commercial growers have already cited temperature management as a primary challenge with low tunnels (Connor and Demchak, 2018). Our results suggest that growers should leave tunnel sides vented as much as possible.

\section{Conclusion}

We show that DN cultivars can add an additional 18 to 20 weeks of fruit production onto the existing 4- to 6-week long season in the northeastern United States, and that first-year marketable yields are likely to surpass what commercial growers currently harvest from short-day cultivars. However, the variation we report among cultivars in yield, fruit size, and SSC, highlights the importance of cultivar selection. Furthermore, the distinct fruiting patterns we observed among cultivars indicates that a combination of cultivars may be required to achieve sufficient yields throughout the prolonged season.

While the inclusion of low tunnels did not increase cumulative marketable or total yield in either year, low tunnels did increase the percent marketable yield, reducing labor inputs for the removal of cull fruit compared with open beds. Low tunnels also increased late-season marketable yield in 1 of 2 years, indicating that the structures can have positive impacts on fruit quality during precipitation and the late-fall season. While we erected low tunnels shortly after planting in both years, our results suggest that low tunnel construction may not be necessary until plants are flowering or when fruit are present. However, deferring low tunnel construction may impact any effects low tunnels have on suppressing runner initiation. Since maximum temperatures reached nearly $20^{\circ} \mathrm{F}$ greater inside low tunnels, we suggest that low tunnel sides be fully vented except for precipitation. We believe this is particularly important during the summer months when ambient temperatures are high.

With high yields, large fruit, and moderate to high SSC, the cultivars Albion, Aromas, Monterey, San Andreas, and Sweet Ann offer great potential to produce strawberry fruit of an exceptional eating quality through the summer and fall in the northeastern United States.

\section{Literature cited}

Anderson, H. 2017. Effects of low tunnel plastic type on organic production of day- neutral strawberries in the upper Midwest. HortScience 52:S442-S443 (abstr.).

Awang, Y.B. and J.G. Atherton. 1995. Growth fruiting responses of strawberry plants grown on rockwool to shading and salinity. Scientia Hort. 62:25-31.

Bagdasarian, J.H. 2012. Strawberry plant named 'Sweet Ann'. U.S. Plant Patent PP22,472 P3. Filed $24 \mathrm{Feb}$. 2009. Issued 31 Jan. 2012.

Ballington, J.R., B. Poling, and K. Olive. 2008. Day-neutral strawberry production for season extension in the Midsouth. HortScience 43:1982-1986.

Black, B.L. 2004. Prohexadione-calcium decreases fall runners and advances branch crowns of 'Chandler' strawberry in a cold-climate annual production system. J. Amer. Soc. Hort. Sci. 129:479-485.

Black, B.L., J.M. Enns, and S.C. Hokanson. 2002. A comparison of temperate-climate strawberry production systems using eastern genotypes. HortTechnology 12:670675 .

Bornt, C.D., J.B. Loy, W.G. Lord, and O.S. Wells. 1998. Annual strawberry production in New England Proc. Natl. Agr. Plastics Congr. 27:99-105.

Bringhurst, R.S. and V. Voth. 1991. Strawberry plant named 'Seascape'. U.S. Plant Patent 7,614. Filed 13 Feb. 1990. Issued 6 Aug. 1991.

Capocasa, F., F. Balducci, C. Martellini, and A. Albanesi. 2017. Yield and fruit quality of strawberry cultivars grown in organic farming in the mid-Adriatic area. Acta Hort. 1156:619-626.

Chi, W., R. Wang, and C. Zhang. 2001. Changes of photosynthetic characteristics of strawberry leaf under shading. J. Appl. Ecol. 12(4):566-568.

Condori, B., D.H. Fleisher, and K. Lewers. 2017. Relationship of strawberry yield with microclimate factors in open and covered raised-bed production. Trans. Amer. Soc. Agr. Biol. Eng. 60(5):15111525.

Connor, D.S. and K. Demchak. 2018. Farmer perceptions of tunnels for berry production: Management and marketing implications. HortTechnology 28:706710.

Correia, P.J., M. Pestana, F. Martinez, E. Ribeiro, F. Gama, T. Saavedra, and P. Palencia. 2011. Relationship between strawberry fruit quality attributes ad crop load. Scientia Hort. 130(2):389-403.

Durner, E.F., J.A. Barden, D.G. Himelrick, and E.B. Poling. 1984. Photoperiod and temperature effects on flower and runner development in day-neutral, junebearing, 
and everbearing strawberries. J. Amer. Soc. Hort. Sci. 109:396-400.

Galletta, G.J. and R.S. Bringhurst. 1990. Strawberry management, p. 109-112. In: G.J. Galletta and D.G. Himekick (eds.). Small fruit management. Prentice Hall, Englewood Cliffs, NJ.

Green, D.W. and S.G. Schloemann. 2010. Prohexadione-calcium inhibits runner formation and enhances yield of strawberry. J. Amer. Pomol. Soc. 64(3): 125-139.

Grubinger, V. 2012. History of the strawberry. 11 Feb. 2019. <https://www.uvm.edu/ vtvegandberry/factsheets/strawberryhistory. html>.

Handley, D. 2008. Strawberry varieties for Maine: How do I grow strawberries in the off-season? Univ. Maine Ext. Bul. 2184. 4 Feb. 2019. <https://extension. umaine.edu/publications $/ 2184 \mathrm{e} />$.

Handley, D. 2017. Getting started in strawberries - Plasticulture. New England Veg. Fruit Conf. Trade Show Proc. p. $79-83$.

Handley, D.T., J.F. Dill, and R.E. Moran. 2009. Prohexadione-calcium applications to suppress runner growth in strawberries grown in a plasticulture system. Acta Hort. 842:801-804 (abstr.). doi:10.17660/ ActaHortic.2009.842.176.

Kadir, S., G. Sidhu, and K. Al-Khatib. 2006. Strawberry (Fragaria $x$ ananassa Duch.) growth productivity as affected by temperature. HortScience 41:14231430 .

Kirschbaum, D.S., E.G.A. Adlercreutz, and N. Gariglio. 2017. Growth and production patterns of strawberries grown in the Atlantic coast of Argentina. Acta Hort. 1156:941-946.

Lantz, W., H. Swartz, K. Demchak, and S. Frick. 2010. Season-long strawberry production with everbearers for northeastern producers. Univ. Maryland Ext. EB 401.

Laugale, V., S. Dane, L. Lepse, S. Strautina, and I. Kalnina. 2017. Influence of low tunnels on strawberry production time and yield. Acta Hort. 1156:573-578.

Lawrence, F.J., G.J. Galletta, and D.H. Scott. 1990. Strawberry breeding work of the United States Department of Agriculture. HortScience 25:895-896.

Ledesma, N.A. and S. Kawabata. 2016. Response of two strawberry cultivars to severe high temperature stress at different flower development stages. Scientia Hort. 211:319-327.

Ledesma, N.A., M. Nakata, and N. Sugiyama. 2008. Effect of high tempera- tures stress on reproductive growth of strawberry cvs. 'Nyoho' and 'Toyonoka'. Scientia Hort. 116:186-193.

Legard, D.E., C.L. Xiao, J.C. Mertely, and C.K. Chandler. 2000. Effects of plant spacing and cultivar on incidence of Botrytis fruit rot in annual strawberry. Plant Dis. 84(5):531-538.

Lewers, K. 2013. Strawberry season extension using low tunnels. 4 Feb. 2019 <http://www.hort.cornell.edu/expo/ proceedings / 2013/Berries/Berries\% 20Lewers\%20Low\%20TTunnel.pdf>.

Lewers, K.S., D.H. Fleisher, and C.S.T. Daughtry. 2017. Low tunnels as a strawberry breeding tool and season-extending production system. Intl. J. Fruit Sci. 17(3):233-258, doi: $10.1080 / 15538362$. 2017.1305941.

Nicoll, M.F. and G.J. Galletta. 1987. Variation in growth and flowering habits of June-bearing and everbearing strawberries. J. Amer. Soc. Hort. Sci. 112:872880 .

Nobel, P.S. 2005. Physicochemical and environmental plant physiology. 3rd ed. Elsevier Sci. Technol./Academic Press. Oxford, UK.

Pérez De Camacaro, M.E., G.J. Camacaro, P. Hadley, M.D. Dennett, N.H. Battey, and J.G. Carew. 2004. Effect of plant density and initial crown size on growth, development and yield in strawberry cultivars Elsanta and Bolero. J. Hort. Sci. Biotechnol. 79(5):739-746.

Petran, A., E. Hoover, L. Hayes, and S. Poppe. 2016. Yield and quality characteristics of day-neutral strawberry in the United States upper Midwest using organic practices. Biol. Agr. Hort. 33(2):1-16.

Pistón, F., A.G. Pérez, C. Sanz, and A. Refoyo. 2017. Relationship between sugar content and ${ }^{\circ}$ Brix as influenced by cultivar and ripening stages of strawberry. Acta Hort. 1156:491-496.

Poling, E.B. 1993. Strawberry plasticulture in North Carolina: II. Preplant, planting, and postplant considerations for growing 'Chandler' strawberry on black plastic mulch. HortTechnology 3:383393.

Poling, E.B. and E.F. Durner. 1986. Annual strawberry hill cultural system in southeastern North Carolina. HortScience 21:240-242.

Pritts, M. 2017a. Protected culture for berries, low and high tunnel research. 8 Mar. 2018. <https://www.youtube. $\mathrm{com} /$ watch? $\mathrm{v}=5$ ErlnTZNuxM $>$.

Pritts, M. 2017b. Low tunnel strawberry production. New England Veg. Fruit Conf. Trade Show Proc. p. 87-98.
Pritts, M. and D. Handley. 1998. Strawberry production guide for the Northeast, Midwest, and eastern Canada. Northeast Reg. Agr. Eng. Serv. (NRAES), Ithaca, NY.

Pritts, M. and L. McDermott. 2017. Protected culture for strawberries using low tunnels. 11 Feb. 2019. <http:// www.hort.cornell.edu/fruit/pdfs/lowtunnel-strawberries.pdf $>$.

Resende, J.T.V., R.G.F. Morales, M.V. Faria, A.L.L. Rissini, L.K.P. Camargo, and C.K. Camargo. 2010. Produtividade e teor de sólidos solúveis de frutos de cultivares de morangueiro em ambiente protegido. Hort. Bras. 28:185-189.

Rowley, D., B. Black, and D. Drost. 2010. High tunnel strawberry production. 4 Feb. 2019. <https://digitalcommons. usu.edu/cgi/viewcontent.cgi? referer=https://www.google.com/\& httpshttps $=1 \&$ article $=1709 \&$ context $=$ extension_curall $>$.

Ruan, J., Y.H. Lee, S.J. Hong, and Y.R. Yeoung. 2013. Sugar and organic acid contents of day-neutral and ever-bearing strawberry cultivars in high-elevation for summer and autumn fruit production in Korea. Hort. Environ. Biotechnol 54(3): 214:222.

Salamé-Donoso, T.P., B.M. Santos, C.K. Chandler, and S.A. Sargent. 2010. Effect of high tunnels on the growth, yields, and soluble solids of strawberry cultivars in Florida. Intl. J. Fruit Sci 10(3):249-263 (abstr.).

Schmitt, J. and R.D. Wulff. 1993. Light spectral quality, phytochrome and plant competition. Trends Ecol. Evol. 8(2):4751

Shaw, D.V. 1998. Strawberry plant named 'Aromas'. U.S. Plant Patent 10,451. Filed 12 Nov. 1996. Issued 16 June 1998.

Shaw, D.V. and K.D. Larson. 2006. Strawberry plant named 'Albion'. U.S. Plant Patent 16,228 P3. Filed 29 Jan. 2004. Issued 31 Jan. 2006.

Shaw, D.V. and K.D. Larson. 2016. Strawberry plant named 'Cabrillo'. U.S. Plant Patent 2016/0227687 P1. Filed 30 Jan. 2015. Issued 4 Aug. 2016.

Shaw, D.V. and K.D. Larson. 2009a. Strawberry plant named 'Monterey'. U.S. Plant Patent PP19,767 P2. Filed 25 Jan. 2008. Issued 24 Feb. 2009.

Shaw, D.V. and K.D. Larson. 2009b. Strawberry plant named 'Portola'. U.S. Plant Patent PP20,552 P3. Filed 6 Nov. 2007. Issued 15 Dec. 2009.

Shaw, D.V. and K.D. Larson. 2009c. Strawberry plant named 'San Andreas'. U.S. Plant Patent PP19,975 P2. Filed 25 Jan. 2008. Issued 12 May 2009. 


\section{Research Reports}

Tabatabaei, S.J., M. Yusefi, and J. Hajiloo. 2008. Effects of shading and $\mathrm{NO}_{3}: \mathrm{NH}_{4}$ ratio on the yield, quality and $\mathrm{N}$ metabolism in strawberry. Scientia Hort. 116:264272 .

Takaichi, M., H. Shimaji, and T. Higashide. 2000. Effects of red/far-red photon flux ratio of solar radiation on growth of fruit vegetable seedlings. Acta Hort. 514:147-156, doi: 10.17660/ActaHortic.2000.514.16.

University of New Hampshire. 2016. Commercial fruit soil report: Recommendations. Univ. New Hampshire Ext. Soil Lab. Rpt., Durham.

University of New Hampshire. 2018. Weather statistics. 26 Nov. 2018. $<$ http://www.weather.unh.edu>.

U.S. Department of Agriculture. 2012. Plant hardiness zone map. 11 Mar. 2019. $<$ https://planthardiness.ars.usda.gov/ $\mathrm{PHZMWeb} />$.
U.S. Department of Agriculture National Agricultural Statistics Service. 2018. New England vegetable and strawberry report, 2017 crop. U.S. Dept. Agr., Washington, DC.

U.S. Department of Agriculture Natural Resource Conservation Service. 2016. Soil series classification: Charlton. 25 Mar. 2019. <https://soilseries.sc.egov. usda.gov>.

Van Sterthem, A., Y. Desjardins, L. Gauthier, Y. Medina, and A. Gosselin. 2017. Use of low tunnels to improve the productivity of day-neutral strawberry plants under the Québec climatic conditions. Acta Hort. 1156:555-562.

Voća, S., B. Duralija, J. Družić, M. Skendrović Babojelić, N. Dobričević, and Z. Čmelik. 2007. Influence of cultivation systems on physical and chemical composition of strawberry fruits cv. Elsanta. Agr. Conspectus Sci. 71(4):171-174.
Voth, V. and R.S. Bringhurst. 1990. Culture and physiological manipulation of California strawberries. HortScience 25:889-892.

Wang, S.Y. and M.J. Camp. 2000. Temperatures after bloom affect plant growth and fruit quality of strawberry. Scientia Hort. 85:183-199.

Weber, C., R. Gassier, K. Kuehn, and M.P. Pritts. 2018. Yield of day-neutral strawberries grown under low tunnels is affected by planting date. HortScience 53:S171 (abstr.).

Wein, H.C. 2009. Microenvironmental variations within the high tunnel. HortScience 44:235-238. 


2017
\begin{tabular}{|c|c|c|c|c|c|c|c|}
\hline SS & M & P & P & SA & A & AR & SA \\
\hline P & SS & AR & SS & A & SA & M & SS \\
\hline M & AR & M & SA & SS & M & SS & P \\
\hline AR & P & SA & A & AP & SS & A & M \\
\hdashline SA & SA & A & AR & M & P & P & A \\
\hline A & A & SS & M & P & AR & SA & AR \\
\hline $\begin{array}{c}\text { ROW 1: } \\
\text { LOW } \\
\text { TUNNEL }\end{array}$ & $\begin{array}{c}\text { ROW 2: } \\
\text { OPEN } \\
\text { BED }\end{array}$ & $\begin{array}{c}\text { ROW 3: } \\
\text { OOEN } \\
\text { BED }\end{array}$ & $\begin{array}{c}\text { ROW 4: } \\
\text { LUW } \\
\text { TUNEL }\end{array}$ & $\begin{array}{c}\text { ROW 5: } \\
\text { OPEN } \\
\text { BED }\end{array}$ & $\begin{array}{c}\text { ROW } 6: \\
\text { LOW } \\
\text { TUNNEL }\end{array}$ & $\begin{array}{c}\text { ROW 7: } \\
\text { OPEN } \\
\text { BED }\end{array}$ & $\begin{array}{c}\text { ROW } 8: \\
\text { LW } \\
\text { TUNNEL }\end{array}$ \\
\hline BLOCK 1 & BLOCK 2 & BLOCK 3 & BLOCK 4 \\
\hline
\end{tabular}

2018
\begin{tabular}{|c|c|c|c|c|c|c|c|}
\hline P & SA & A & CA & SS & SA & M & SS \\
\hline M & SS & CA & A & P & CA & SS & M \\
\hline SS & A & SW & SS & M & SS & P & P \\
\hline CA & P & M & SA & SW & A & CA & SW \\
\hline SA & SW & P & M & CA & SW & A & SA \\
\hline A & CA & SA & P & A & M & SA & A \\
\hline SW & M & SS & SW & SA & P & SW & CA \\
\hline $\begin{array}{c}\text { ROW 1: } \\
\text { LOW } \\
\text { TUNNEL }\end{array}$ & $\begin{array}{c}\text { ROW 2: } \\
\text { OPEN } \\
\text { BED }\end{array}$ & $\begin{array}{c}\text { ROW } 3: \\
\text { OPEN } \\
\text { BED }\end{array}$ & $\begin{array}{c}\text { ROW 4: } \\
\text { LUWNEL } \\
\text { TUNN }\end{array}$ & $\begin{array}{c}\text { ROW } 5: \\
\text { LOW } \\
\text { TUNNEL }\end{array}$ & $\begin{array}{c}\text { ROW } 6: \\
\text { OPEN } \\
\text { BED }\end{array}$ & $\begin{array}{c}\text { ROW 7 } \\
\text { LOW } \\
\text { TUNNEL }\end{array}$ & $\begin{array}{c}\text { ROW 8: } \\
\text { OPEN } \\
\text { BED }\end{array}$ \\
\hline BLOCK 1 & BLOCK 2 & BLOCK 3 & BLOCK 4 \\
\hline
\end{tabular}

Supplemental Fig. 1. Experimental design for day-neutral strawberry experiments conducted in 2017 and 2018 at the University of New Hampshire in Durham. The experiment was arranged in a split-plot randomized complete block design with four replications. The main-plot was cover treatment, and consisted of traditional open beds and low tunnels covered by 1.5 - $\mathrm{mil}(0.038 \mathrm{~mm})$ plastic. The sub-plot was cultivar, and a total of six cultivars were evaluated in 2017 and seven in 2018. Cultivars were: Albion (A), Aromas (AR), Cabrillo (CA), Monterey (M), Portola (P), San Andreas (SA), Seascape (SS), and Sweet Ann (SW). Sub-plots consisted of 10 plants in 2017 and 14 plants in 2018, and were established one directly after another the length of each row. 